\title{
Preliminary Safe-Handling Experiments on a Mixture of Cesium Nickel Ferrocyanide and Equimolar Sodium Nitrate/Nitrite
}
R. D. Scheele

H. H. Cady

January 1992

Prepared for the U.S. Department of Energy under Contract DE-AC06-76RLO 1830

Pacific Northwest Laboratory

Operated for the U.S. Department of Energy by Battelle Memorial Institute 


\title{
DISCLAIMER
}

This report was prepared as an account of work sponsored by an agency of the United States Governn ent. Neither the United States Government nor any agency thereof, nor Battelle Memorial Institute, nor any of their employees, makes any warranty, expressed or implied, or assumes any legal liability or responsibility for the accuracy, completeness, or usefulness of any information, apparatus, product, or process disclosed, or represents that its use would not infringe privately owned rights. Reference herein to any specific commercial product, process, or service by trade name, trademark, manufacturer, or otherwise does not necessarily constitute or imply its endorsement, recommendation, or favoring by the United States Government or any agency thereof, or Battelle Memorial Institute. The views and opinions of authors expressed herein do not necessarily state or reflect those of the United States Government or any agency thereof.

\author{
PACIFIC NORTHWEST LABORATORY \\ operated by \\ BATTELLE MEMORIAL INSTITUTE \\ for the \\ UNITED STATES DEPARTMENT OF ENERGY \\ under Contract DE-AC06-76RLO 1830
}

Printed in the United States of America

Available to DOE and DOE contractors from the

Office of Scientific and Technical Information, P.O. Box 62, Oak Ridge, TN 37831; prices available from (615) 576-8401. FTS 626-\$3401.

Available to the public from the National Technical Information Service,

U.S. Department of Commerce, 5285 Port Royal Rd., Springfield, VA 22161. 
PRELIMINARY SAFE-HANDLING EXPERIMENTS ON A MIXTURE OF CESIUM NICKEL FERROCYANIDE AND EQUIMOLAR SODIUM NITRATE/NITRITE

R. D. Scheele
H. H. Cady

January 1992

Prepared for the U.S. Department of Energy under Contract DE-ACO6-76RLO 1830

Pacific Northwest Laboratory Richland, Washington 99352

(a) Los Alamos National Laboratory. 


\section{SUMMARY}

As part of the Hanford Site's evaluation of the potential hazards associated with the storage of ferrocyanide wastes generated when ferrocyanide was used to scavenge radiocesium from waste supernates in the 1950 s, the Pacific Northwest Laboratory (PNL) subcontracted with Los Alamos National Laboratory (LANL) to perform a series of sensitivity tests. These tests supplement PNL's thermal sensitivity testing results on the reactivity of cesium nickel ferrocyanide $\left(\mathrm{Cs}_{2} \mathrm{NiFe}(\mathrm{CN})_{6}\right)$ and nitrates and nitrites (Burger and Scheele 1991). LANL used a selected set of their standard tests to determine the sensitivity of a mixture of $\mathrm{Cs}_{2} \mathrm{NiFe}(\mathrm{CN})_{6}(\mathrm{FECN}-1)$ and equimolar sodium nitrate and nitrite oxidant to nonthermal and thermal stimuli. The stoichiometric ratio of oxidant to $\mathrm{Cs}_{2} \mathrm{NiFe}(\mathrm{CN})_{6}$ in the tested mixture $\mathrm{FECN}-1$ was $1.1: 1$.

The appendix presents the results of the LANL testing of the sensitivity of FECN-1 to initiation by mechanical impact, spark, friction, and various thermal conditions. In addition to the sensitivity testing, LANL used an Accelerating Rate Calorimeter (ARC) to estimate the behavior of large batches of the mixture.

The results of the LANL testing show that the reactions of $\mathrm{Cs}_{2} \mathrm{NiFe}(\mathrm{CN})_{6}$ and equimolar sodium nitrate and nitrite are not sensitive to initiation by mechanical impact or friction within the limits of the LANL tests. However, reactions between the mixture components can be initiated by high energy sparks and by thermal events. The ARC experiments found exothermic reaction behavior at temperatures as $10 \mathrm{w}$ as $210^{\circ} \mathrm{C}$. The ARC results were inconclusive as to whether a large-scale thermal test would initiate a thermal runaway reaction below $230^{\circ} \mathrm{C}$. 


\section{CONTENTS}

SUMMARY ................................. i . . . . . .

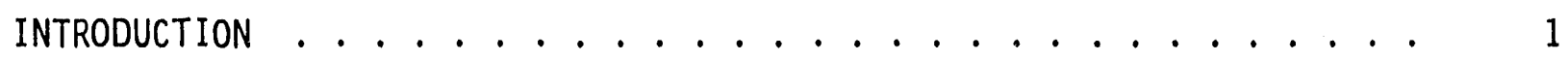

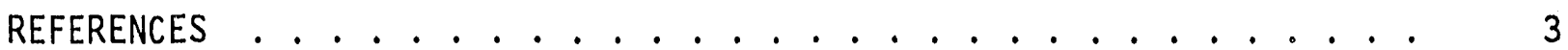

APPENDIX A - PROJECT REPORT: PRELIMINARY SAFE-HANDLING

EXPERIMENTS ................... A.1 


\section{INTRODUCTION}

As part of the Hanford Site's evaluation of the potential hazards associated with the storage of ferrocyanide wastes generated when ferrocyanide was used to scavenge radiocesium from waste supernates in the 1950s, the Pacific Northwest Laboratory (PNL) subcontracted with Los Alamos National Laboratory (LANL) to perforin a series of sensitivity tests. These tests supplement PNL's thermal sensitivity testing results on the reactivity of cesium nickel ferrocyanide $\left(\mathrm{Cs}_{2} \mathrm{NiFe}(\mathrm{CN})_{6}\right)$ and nitrates and nitrites (Burger and Scheele 1991). LANL used a selected set of their standard tests to determine the sensitivity of a mixture of $\mathrm{CS}_{2} \mathrm{NiFe}(\mathrm{CN})_{6}$ ( $\mathrm{FECN}-1$ ) and equimolar sodium nitrate and nitrite oxidant to nonthermal and thermal stimuli. The stoichiometric ratio of oxidant to $\mathrm{Cs}_{2} \mathrm{NiFe}(\mathrm{CN})_{6}$ in the tested mixture $\mathrm{FECN}-1$ was $1.1: 1$.

The appendix presents the results of the LANL testing of the sensitivity of FECN-1 to initiation by mechanical impact, spark, friction, and various thermal conditions. In addition to the sensitivity testing, LANL used an Accelerating Rate Calorimeter (ARC) to estimate the behavior of large batches of the mixture. 


\section{REFERENCES}

Burger, L. L., and R. D. Scheele. 1991. The Reactivity of Cesium Nickel Ferrocyanide Towards Nitrate and Nitrite Salts. PNL-7550. Pacific Northwest Laboratory, Richland, WA. 
APPENDIX A

PROJECT REPORT: PRELIMINARY SAFE-HANDLING EXPERIMENTS 
CONTENTS

Introduction . . . . . . . . . . . . . . . . . A.1

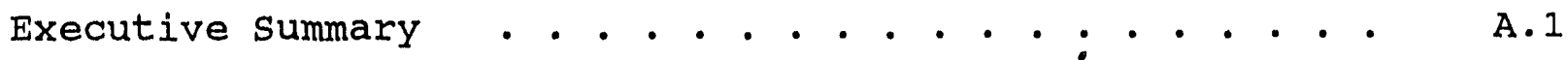

Purpose of the Experiments . . . . . . . . . . . . A.2

Test Results and Assessments . . . . . . . . . . . A.3

1. Impact Sensitivity . . . . . . . . . . . . A.4

2. Friction Sensitivity . . . . . . . . . . A.8

3. Spark Sensitivity . . . . . . . . . . . A.10

4. Preliminary Thermal Properties . . . . . . . A.13

A. iii 


\section{FIGURES}

1 Drop-Weight Impact Machine . . . . . . . . . . A.5

2 Type 12 Tools . . . . . . . . . . . . . . . . A.6

3 Configuration of the Sample, Porcelain Peg,
and Plate in a BAM Friction Tester . . . . . . . . A.9

4 Exploded View of Spark-Sensitivity

Sample Holder .. . . . . . . . . . . . . A.11

5 Schematic of DuPont DTA Cell and

Thermocouples . . . . . . . . . . . . . A.15

6 DuPont DTA Curve of FECN-1 . . . . . . . . . . . . . A.16

7 DuPont DTA Curve of FECN-1 Emphasizing A.16

8 FECN-1 DTA Curves as a Function of

Heating Rate.. . . . . . . . . . . . . . A.17

FECN-1 DTA Curve Showing Variation in
Exotherm Shape . . . . . . . . . . . . . . . .

10 Routine DTA Cell Assembly . . . . . . . . . . . A.19

11 Routine DTA and Pyrolysis Curves for FECN-1 . . . . A.19

12 Schematic Drawing of Pyrolysis Apparatus . . . . . . A.21

13 Pyrolysis Block . . . . . . . . . . . . . A.22

14 VTS Manometer Tube and Cell . . . . . . . . . . A.24

15a VTS Gas Evolution for FECN-1 . . . . . . . . . . A.25

15b VTS Gas Evolution for 900-10 Inert . . . . . . . . A.26

16 Henkin-Test Metal-Bath Assembly . . . . . . . . . A.28

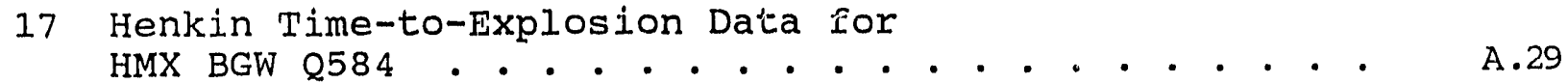

18 Henkin Time-to-Explosion Data for FECN-1 . . . . . . A.29

19 ARC Internal Logic Schematic . . . . . . . . . . A.32 
20 Typical ARC Step Run with Exothermic

21 ARC Calorimeter Package and Sample Cell . . . . . . A.34 
TABLES

1 Impact Sensitivity . . . . . . . . . . A.7

2 Friction Sensitivity . . . . . . . . . . . A.9

3 Spark Sensitivity (3-mil Foil) . . . . . . . . A.12

4 Spark Sensitivity (10-mil Foil) . . . . . . . A A.12

5 Vacuum Thermal Stability . . . . . . . . . . A.26

6 Henkin Critical Temperature . . . . . . . . A.30 


\title{
PROJECT REPORT: \\ PRELIMINARY SAFE-HANDLING EXPERIMENTS
}

\author{
Intercontractor Memorandum Purchase order No. 095507-A-F1 \\ Between Pacific Northwest Iaboratory \\ and \\ Los Alamos National Laboratory \\ Prepared by: Howard H. Cady
}

\section{Introduction}

Los; Alamos National Laboratory (IANL) agreed to assist Pacifj.c Northwest Laboratory (PNL) in the Ferrocyanide Safety Evaluation Program by helping to evaluate the explosive hazard of a mixture of nickel cesium ferrocyanide with sodium nitrate and sodium nitrite $($ FECN-1). This is an evaluation of the small-scale safety tests that had to be completed before large-scale tests could be performed at IANL. This series of laboratory tests was performed to evaluate handling hazards and determine ease of initiation of chemical reaction by impact, friction, electrical spark, and heat. The FECN-1 mixture, prepared by PNL and sent to LANL for testing, was composed of $12 \mathrm{~g}$ of hydrated cesium nickel ferrocyanide and $13 \mathrm{~g}$ of an equimolar mixture of sodium nitrate and sodium nitrite.

\section{Executive Summary}

The FECN-1 mixture was tested at LANL. FECN-1 proved safe to handle from an explosives point of view and did not react under the most severe conditions of our impact or friction tests. No significant permanent gas was evolved in a $48-\mathrm{h}, 120^{\circ} \mathrm{C}$ vacuum-stability test. Reactions were observed in the spark-sensitivity test at energies much higher than are required to ignite all but the most insensitive explosives. The Henkin Critical Temperature was $367^{\circ} \mathrm{C}$ for a $0.04-\mathrm{g}$ sample with a diameter of $1 / 4$ in. and a thickness of $0.573 \mathrm{~mm}$. The critical temperature is defined as the temperature at which heat is generated faster in the sample than it can be conducted to a surrounding fixed-temperature bath. In the pyrolysis test, small amounts of gas (probably water) were evolved from the mixture at about $160^{\circ} \mathrm{C}$, and larger amounts were observed at temperatures above $290^{\circ} \mathrm{C}$. Differential Thermal Analysis (DTA) showed two distinct endotherms below $240^{\circ} \mathrm{C}$, as well as exotherms that depended on heating rate at temperatures above $280^{\circ} \mathrm{C}$. The Accelerating Rate calorimeter (ARC) is much more sensitive to exotherms than is DTA, and ARC experiments showed exotherms at temperitures as low as $210^{\circ} \mathrm{C}$. However, it was not clear from our experiments whether a large mass of FECN-1 would cook-off before about $250^{\circ} \mathrm{C}$ because the DTA endotherm at $230^{\circ} \mathrm{C}$ might have been sufficient to quench the $210^{\circ} \mathrm{C}$ exotherm and prevent heating to $250^{\circ} \mathrm{C}$ where a second exotherm was observed. This information does not imply that it would be safe to heat a large quantity of $\mathrm{FECN}-1$ to, say, $200^{\circ} \mathrm{C}$. Rather, it should be interpreted to mean that we already have reason to 
believe it may be unsafe to heat large quantities o\% FECN-1 to $200^{\circ} \mathrm{C}$. The equation, on page A.27, relating calculated critical temperature with physical, chemical, and geometric factors shows that the larger the amount of available FECN-1, the lower would be the hazardous temperature. However, it is not scientifically sound to extrapolate high-temperature measurements to temperature regions where the kinetic mechanism will differ. A break in mechanism will occur at the eutectic melting point. The DTA curves showed endotherms at temperatures of $180^{\circ}$ and $220^{\circ} \mathrm{C}$ where substantial changes in rates of chemical reaction are likely. prediction of a thermal hazard at temperatures below these endotherms that is based on higher temperature data is not technically sound and will predict a hazard when one does not, in fact, exist.

The preliminary small-scale tests conducted at LANL indicated that purely mechanical insult to FECN-1 should not wause any chemical reaction that could grow to an explosion. FECN-1 was found to react with evolution of gas at temperatures above $200^{\circ} \mathrm{C}$, and the rate of reaction increases with temperature. This indicated a potential for explosion if large quantities of $\mathrm{FECN}-1$ reach temperatures above $200^{\circ} \mathrm{C}$. Large-scale tests should be conducted to better determine the cook-off behavior of FECN-1.

\section{Purpose of the Experiments}

The purpose of the experiments conducted for this report is to learn enough about the explosive sensitivity properties of FECN-1 as a loose powder so that it can be placed in a hazard class relative to other known energetic materials. In addition, enoligh thermal decomposition information is needed to plan large-scale tests.

The sensitivity of an explosive material is not a well-defined property of the material, expressible as a single number, but instead is a complex pattern of behavior. In the present context, the sensitivity of an explosive refers to the probability that it will undergo a sudden partial or complete decomposition when subjected to stimulus. Different sensitivity tests, even when intended to measure the same property, will frequently produce different orders of relative sensitivity for a given series of explosive materials. In other words, there is not even a unique qualitative scale of sensitivity. The sensitivity of an explosive material depends on numerous chemical, physical and mechanical factors, some controllable, some not. In sensitivity tests, the response of an explosive varies in seemingly random fashion over some range of severity of the applied stimulus. That is, there is no sharp threshold above which the explosive will always explode, or below which it will never explode. 
The response of an explosive to a stimulus may be partial, even minute, or it may be a complete, high-order detonation. Three particular sensitivity characteristics are of special importance:

1. the ease with which a detectable reaction of any sort can be produced in the material

2. the tendency of any small reaction, once started, to grow to destructive proportions

3. the ease with which a high-order detonation can be established in the material.

The second sensitivity characteristic could not be completely separated from the first, but one can obtain a "feel" for this tendency from the variation in magnitude of response to identical stimuli. our small-scale tests of FECN-1 did not indicate any unusual tendencies of small reactions to easily grow into large reactions. We did not directly address the third item in our tests of FECN-1. only primary explosives detonate in the small-scale tests we used, and FECN-1 is clearly not a primary explosive.

At LANL, we require a determination of impact, friction, spark, and thermal sensitivities before we feel confident to place a new energetic material in a handling-hazard classification. In effect, these tests rank the material by a combination of the first and second characteristics for several types of stimulus common in accidents.

\section{Test Results and Assessments}

Results from tests that measure the sensitivity of explosives vary significantly when samples are contaminated with liquids such as oil or water. The FECN-1 sample was reported to be a nonhygroscopic hydrate. This meant that it could not be oven or vacuum dried without a risk of changing its sensitivity. Shortly after the FECN-1 sample arrived at LANL, it was determined that an aliquot would lose about $2 \%$ of its weight on exposure to a $20 \%$ relative humidity (RH) ambient Los Alamos atmosphere. The weight of the aliquot then seemed to depend on $\mathrm{RH}$, gaining weight when the humidity increased and losing weight when humidity decreased. Pacific Northwest Laboratory and LANL jointly decided that LANL would not try to determine the reason for the change in weight, but would record $\mathrm{RH}$ when sensitivity measurements were taken. All sensitivity measurements were completed before the summer monsoon season began. During this period, the test aliquot weighed less than its initial weight. After the monsoon season, with a $50 \% \mathrm{RH}$, the aliquot weighed more than it did initially. 
1. Impact Sensitivity

(S. S. Hildner, R. D. Steele)

In the broadest sense, the drop-weight impact test will indicate the likelihood of an explosive producing unwanted, accidental reactions when it is subjected to the iniscellaneous impacts, scrapings, pinchings, and drops incidental to research, development, manufacture, loading, and use. or, to restate, the test should tell us how careful we must be to avoid unwanted reactions while handling the material. Unfortunately, history has shown that although the impact test is our most useful test, its results are not adequate to provide predictions of all possible handling accidents.

The drop-weight impact machine used at LANL is based on a design that the Explosives Research Laboratory at Bruceton, Pennsylvania, developed during World War II. The bulk of the machine (Figure 1) consists of a device for hoisting, releasing, and guiding the $2.5-\mathrm{kg}$ free-falling weight, and a massive steel and concrete base. The most critical parts, so far as results are concerned, are the tools illustrated in Figure 2 . The hardened steel anvil is fimly seated on the steel base by the anvil holder. In the Type..$"$ "set, a 40-mg sample of the explosive under test is places in a shollow depression in a $2.5-\mathrm{cm}$ square of 5/0 garnet san vaper, which is then placed on the anvij. The hardened-steel "iriker is carefully lowered through the guide ring onto the simnle, and the weight is then raised to the desired height and a nuped onto the striker. The Type $12 \mathrm{~B}$ test is similar except that the striker and anvil surfaces are roughened by sandblasting with No. 40 Carborundum, and the 40-mg sample is placed directly on the roughened anvil.

The reaction of the sample may range anywhere from completely inert to a fairly violent explosion. Sensitive explosives, such as PETN, usually react violently or not at all, while less sensitive materials, such as TNT, will produce a wide range of partial explosions. While there is a general, but variable, increase in extent of reaction with drop height, it is convenient to classify the results of each drop as either an $E$ (event) or an $\mathrm{N}$ (no reaction).

Because small reactions are difficult to detect, and human ears vary in sensitivity, a "noise meter" consisting of a microphone and a "black box" is used to determine whether the result of a given drop is an $\mathrm{E}$ or an $\mathrm{N}$. A knob is used to vary the sensitivity of the noise meter; the meter at LANL reports an $E$ when about $5 \%$ or more of a normal high-explosive sample reacts. The noise meter also records the loudness of the explosion on a discrete scale. A fresh sample is used for each drop. 


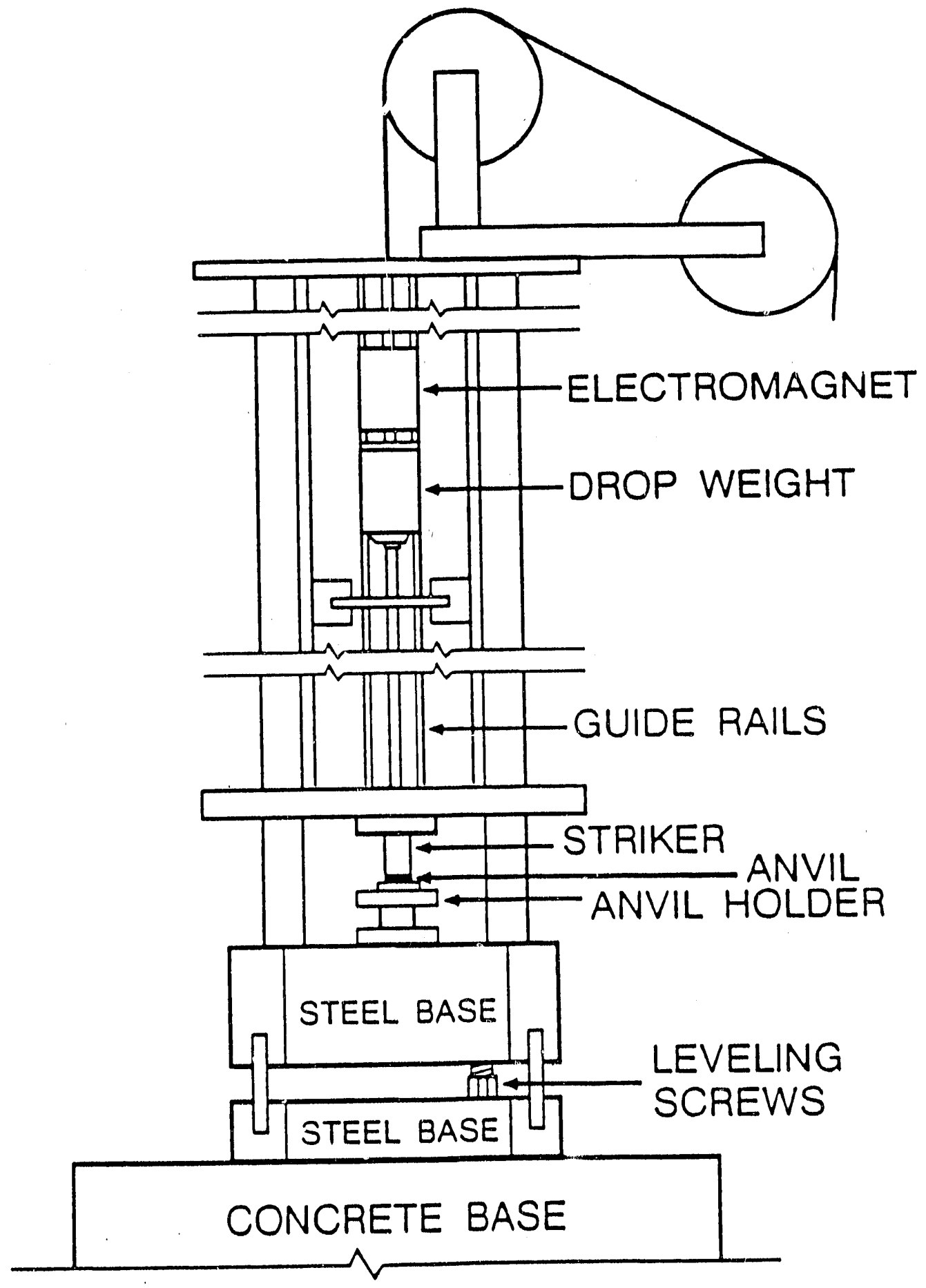

Figure 1. Drop-Weight Impact Machine 


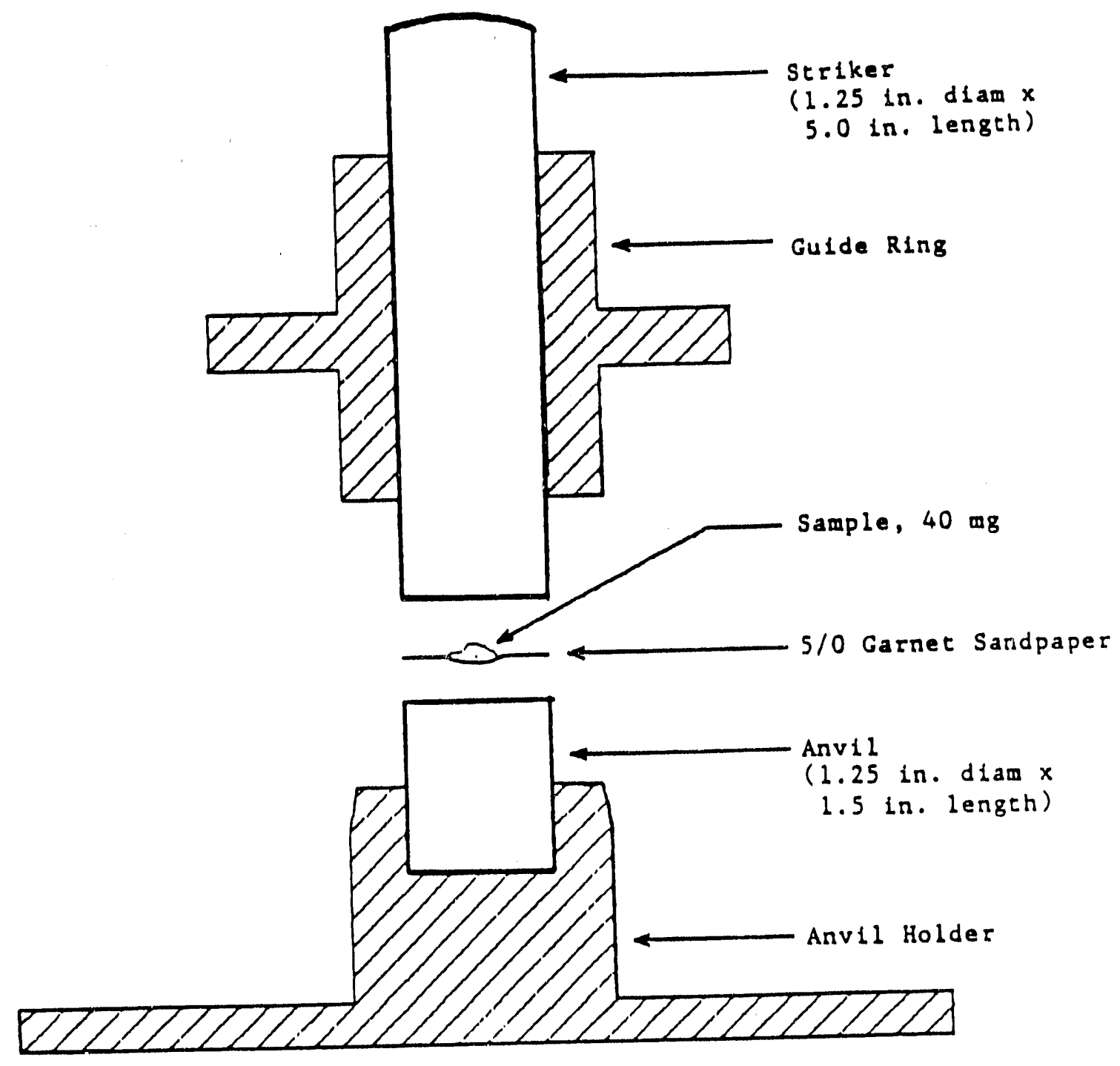

Figure 2. Type 12 Tools

A standard test consists of 25 shots performed by following the "up and down" Bruceton testing technique normally used in sensitivity testing. The results are reported in terms of the height at which an $\mathrm{E}$ is obtained $50 \%$ of the time $\left(\mathrm{H}_{50}\right)$. The intervals used at IAANL are 0.05 times the logarithm (base 10) of the preceding drop height. The logarithmic scale is used on the assumption that the heights at which events occur follow a lognormal distribution. A short series of 10 drops is used when the first 10 drops are all $\mathrm{Ns}$ at a drop height of $320 \mathrm{~cm}$. This height is the maximum drop used at LANL. In this case, $\mathrm{H}_{50}$ was reported as "No Go at 320 " or $>320$. 
It is normal to intermix arops on a known standard material with drops on the unknow materials to ensure that the impact machine is working properly. The standard material for this study was HMX Lo" LANL.

Impact sensitivity can be a function of both sample weight and sample densim" For this reason, it was decided to run some impacts on situling that were of standard volume in addition to the weighed otiluples. The result of this experiment was to show that the buik lensity of FECN-1 is the same as that of the HMX standard.

The actual drop tests were completed in one afternoon. The RH was $34 \%$ at the beginning of the run and $32 \%$ at the end. Type 12 test drops were perfor: ad before the Type 12B drops. Noise ineter readings for the $\mathrm{Ns}$ were recorded on the data sheets. Ihe results are summarized in Table 1. Accepted values for other common explosives are also included.

The vallues measured for the HMX standard are within normal range and indicate proper functioning of the impact machine. FECN w. is so insensitive that it is beyond the range at which explosive materials can be ranked by our Impact sensitivity Test: Materials in this range are considered quite safe to impart stimulus.

Table 1. Impact Sensitivity

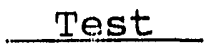

Type 12

Type 12B

\begin{tabular}{l} 
Sample \\
\hline HMX HOL $41-57$ \\
HMX Standard (Avg.) \\
FECN-1 (weighed) \\
FECN-1 (volume) \\
PETN (Handbook) \\
RDX (Handbook) \\
TNT (Handbook) \\
TATB (Handbook) \\
HMX HOL $41-57$ \\
HMX Standard (Avg.) \\
FECN-1 (weighed) \\
FECN-1 (volume) \\
PETN (Handbook) \\
RDX (Handbook) \\
TNT (Handbook) \\
TATB (Handbook)
\end{tabular}

$$
\begin{aligned}
\mathrm{H}_{50}(\mathrm{~cm}) \\
34 \cdot 3 \\
34.4 \pm 1.8 \\
>320 \\
>320 \\
12-16 \\
23-28 \\
157 \\
>320 \\
41.5 \\
45 \cdot 4 \pm 3.9 \\
>320 \\
>320 \\
13-20 \\
23-28 \\
>320 \\
>320
\end{aligned}
$$




\section{Friction Sensitivity}

(G. Jio, R. D. Steele)

Friction is commonly considered an important source of accidental ignition. This is especially true for primary explosives, the more sensitive secondary explosives, certain pyrotechnics, and large charges. Numerous attempts have been made to design small-scale friction tests for use on high explosives. Los Alamos National Laboratory has replaced its sliding-torpedo frijtion test with the large Bundesanstalt für Materialprüungen (BAM) friction testing machine manufactured by Julius Peters GmbH, Berlin, Germany, because the BAM machine obtains responses from a wider range of explosives than the older LANL design. However, it still remains the case that only the more sensitive secondary explosives yield responses during testing.

The BAM friction-testing machine consists of a friction device mounted on a cast-steel base plate. The friction device is made of a fixed porcelain peg and a moveable porcelain plate. The plate is held in a cradle that slides between two rails. The cradle is driven by a rod, an eccentric pulley, and a transmission gear with a grab clutch powered by an electric motur. The plate is moved under the peg with a backward and forward motion of $10 \mathrm{~mm}$. The porcelain peg is loaded by means of a lever arm and fixed weights. The load on the peg can be varied from 0.5 to $36 \mathrm{~kg}$.

The unglazed porcelain plates are composed of white technical porcelain. Both friction surfaces of the plates are coarsened before firing by rubbing with a sponge. These sponge marks are clearly visible. The cylindrical unglazed porcelain pegs are also made from white technical porcelain. They are $15 \mathrm{~mm}$ long, $10 \mathrm{~mm}$ in diameter, and have rough spherical end surfaces with a $10-\mathrm{mm}$ radius of curvature. This coarseness of the plates and peg is an essential prerequisite for the reproducibility of the test; therefore, any given section of these surfaces can be used only once.

Test substances should be dry powders with particle sizes $<0.5 \mathrm{~mm}$. Test results are both visual and audio. Results are categorized as "no reaction," "decomposition," (discoloration, smel1), "flash or flame," "snap," or "explosion." The first two are considered Ns while the latter three are Es.

To begin the test procedure, the porcelain plate was fastened to the sliding cradle so that the sponge marks were perpendicular to the direction of travel. A test sample of about $10 \mathrm{~mm}^{3}$ was then measured onto the plate. The peg was directed into contact with the sample, which lay in the peg's path of 
travel (Figure 3). The appropriate weight was hung on the lever arm, and the clutch was activated.

The load on the rod was varied in steps of $2.4 \mathrm{~kg}$ in the Bruceton up-and-down test sequence, and the statistical value of $\mathrm{Wt}_{50}$ was reported as the sensitivity.

Table 2 summarizes the results of the Friction Sensitivity Test for FECN-1 and the PETN sample that was run concurrently to ensure the machine was functioning properly. The normal values obtained for several explosives also appear in Table 2. The result for the PETN sample is well within the normal range for this material. The $\mathrm{RH}$ was $28 \%$ when the Friction Sensitivity Test was run.

The FECN-1 sample was insensitive enough to test outside the friction sensitivity range established to rank materials. However, it should be noted that the same can be said for many common military explosives because only the more sensitive secondary explosives react in this test. FECN-1 is considered safe to handle according to the Friction sensitivity Test.

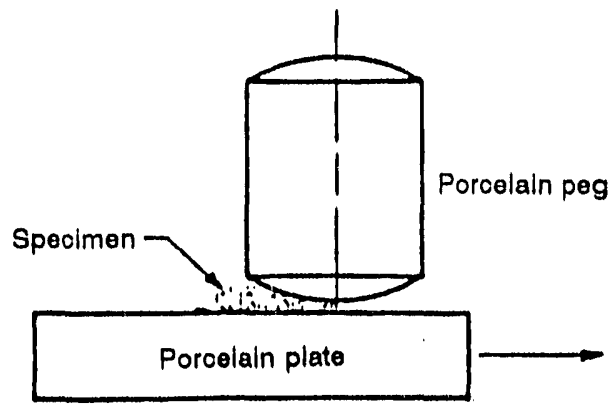

Figure 3. Configuration of the Sample, Porcelain Peg, and Plate in a BAM Friction Tester

Table 2. Friction Sensitivity

\begin{tabular}{lc}
\multicolumn{1}{c}{ Sample } & $\underline{W t}_{50}(\mathrm{~kg})$ \\
\hline FECN-1 & $>36$ \\
PETN (0601-02 RPS-3518) & 8.4 \\
PETN (average value) & $9.6 \pm 1.2$ \\
HMX (average value) & 13.6 \\
RDX (average value) & 17.3 \\
Comp B & $>36$ \\
TNT' & $>36$
\end{tabular}

A. 9 
3. Spark Sensitivity

(S. S. Hildner, R. D. Steele)

Another small-scale safety test used at LANL is the spark Sensitivity Test. In this test, a static electric discharge is passed through the sample. The energy level at which a confining foil is ruptured is the minimum level at which an $\mathrm{E}$ will occur. There are two principal reasons for performing this test. First, Ios Alamos has a dry climate; therefore, it is relatively easy for a human body to develop and retain a significant static charge in normal laboratory operations. Second, we have encountered several explosives that were relatively insensitive to both impact and friction but were quite sensitive to electric discharge. If unrecognized, tilis could lead to extremely hazardous operations in blending or handling processes.

The spark sensitivity of a material is determined by subjecting it to a high-voltage $(5000 \mathrm{~V})$ discharge from a variable capacitance bank. The discharge energy is increased and decreased until the energy level is found that produces an event in $50 \%$ of the samples.

To conduct the test, material is placed in a holder like that shown in Figure 4. A polystyrene sleeve is cemented around a steel dowel leaving a 3/16-in.-dia by 1/4-in.-high space to hold the sample. The sample is placed in the sleeve space and covered with either 3-mil or 10-mil lead foil. A polystyrene clamping ring is then clamped over the sleeve to hold the foil and sample in place. The assembly is then positioned in an enclosed steel box equipped with various interlocks. A capacitor bank charged to $5000 \mathrm{~V}$ and the desired energy level is connected to a pin held in a spring-loaded device resembling a single-stroke sewing machine. The steel dowel provides the ground plane for the electrical circuit. When the needle is released, it is driven rapidly through the lead foil into the sample and then retracted (in about $0.04 \mathrm{~s}$ ). At closest approach, the separation between the needle and the dowel is about $2 \mathrm{~mm}$.

At some point, a discharge occurs in the sample. Four levels of reaction are typically observed: no reaction sufficient to modify the lead foil (an N), deformation of the foil without a rupture (an N), rupture of the foil (a Go and an E), or destruction of the polystyrene holder (an explosion and an $E$ ). Energies are calculated using the equation $E=1 / 2 \mathrm{CV}^{2}$, where $\mathrm{E}=$ spark energy in joules, $\mathrm{C}=$ capacitance in farads, and $\mathrm{V}=$ potential in volts. The 50 percentage points required to categorlze test results as a Go/Explosion (in energy) are determined by the Bruceton up-and-down method. 


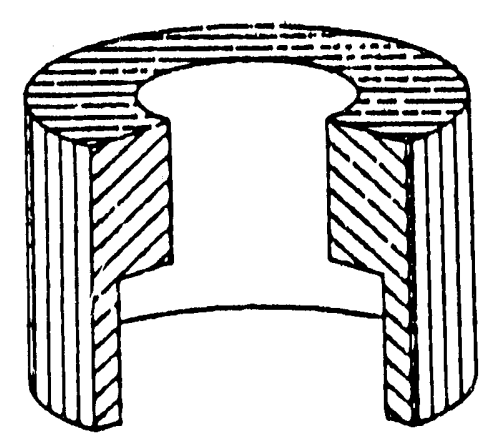

Polystyrene Clamping Ring

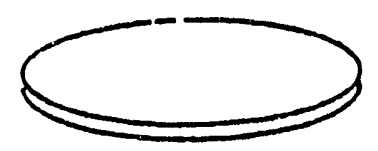

Confining Foil

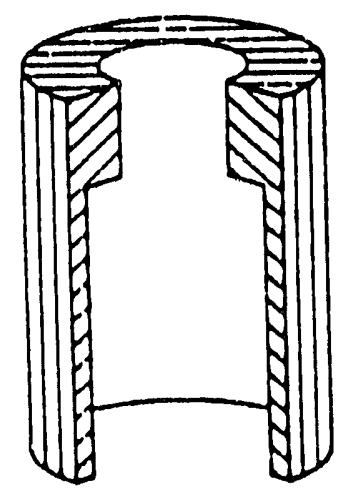

Polystyrene Sleeve

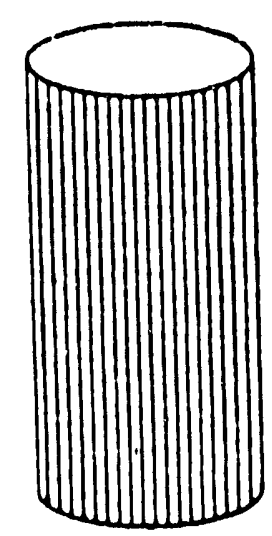

Steel Dowel

Figure 4. Exploded View of Spark-Sensitivity Sample Holder 
The normal up-and-down method was used for the 3-mil ioll test of FECN-1. The 50\% level determined for FECN-1 was lower than that for the insensitive explosive TATB, but substantially higher than that of other common explosives. The 50\% point in the 10-mil foll test was at a very high energy level and reached a point beyond our ability to statisticaliy determine a $50 \%$ Go value. In the series of tests run with 10-mil foils on October 26, 1990, the Go level was clearly $>20 \mathrm{~J}$ and $<26 \mathrm{~J}$.

An HMX standard was run concurrently with the FECN-1 samples to ensure that the spark testing machine was working properly. The results for the spark Sensitivity Tests are summarized in Tables 3 and 4. (Note: the maximum static charge likely to be accumulated on a human body is $0.015 \mathrm{~J}$. Explosions were not observed in the 3-mil foil test for any listed materials.)

In the 10-mil foll test, it was noticed that the sample occasionally burned after the static discharge. This burning was not necessardily an indication of an Event; it was observed for 3 No Goes, 1 Go, and 1 Explosion. Occurrences of burning were recorded on the original data sheets.

Table 3. Spark Sensitivity (3-mil Foil)

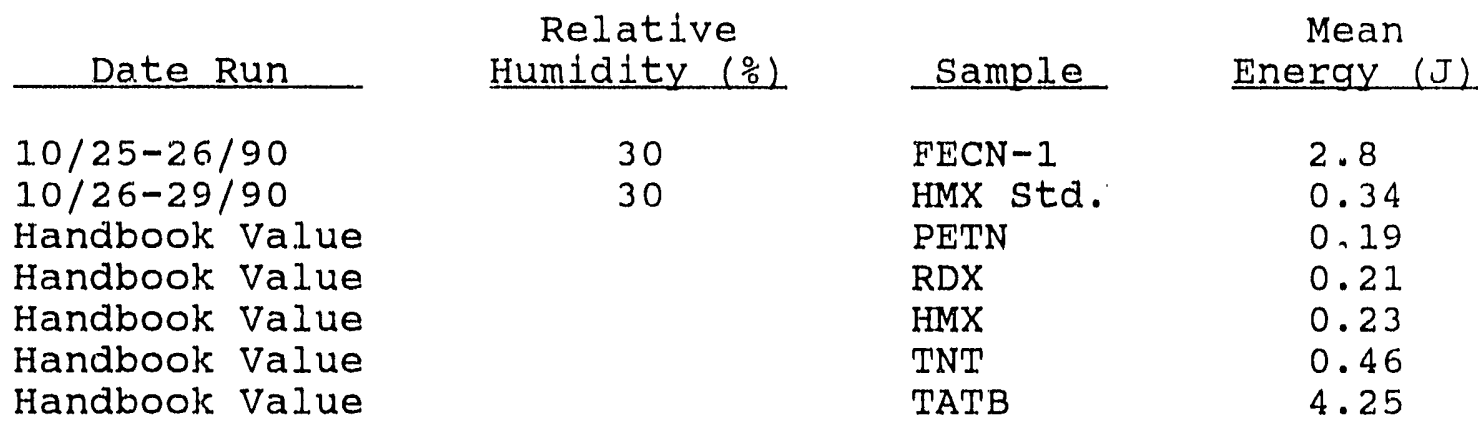

Table 4. Spark Sensitivity (10-mil. Foil)

\begin{tabular}{l} 
Date Run \\
\hline $10 / 26 / 90$ \\
$10 / 25-26 / 90$ \\
Handbook Value \\
Handbook Value \\
Handbook Value \\
Handbook Value \\
Handbook Value
\end{tabular}

Relative

Humidity $(\%)$ Sample Energy (J)

Explosion

Mean

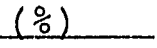

$10 / 26 / 90$

$10 / 25-26 / 90$

30

30

FECN-1
HMX std.
PETN
RDX
HMX
TNT
TATB

$19<$ test $<26$
2.1
0.75
0.96
1.42
3.75
18.1

73

87

8

0

23

0 


\section{Preliminary Thermal properties}

The thermal properties of explosives are important considerations in normal processing evaluations and accident investigations. Los Alamos routinely uses Vacuum stability Tests to evaluate compatibility and heating safety for drying, hot pressing, and desert storage operations. Differential Thermal Analysis is used to look for exothermic and endothermic changes that determine the temperatures of phase changes and chemical reactions. Pyrolysis tests are run to ascertain the temperatures of the reactions that release gaseous products. Samples are lightly confined and small to limit the size of explosions and avoid significant damage. Explosions in any of these tests are considered indications of higher than desirable hazard in thermal environments. Explosions indicate chemical reactions that rapidly accelerate with increasing pressure, and further indicate the type of behavior necessary for deflagration-todetonation transitions. FECN-1 showed no evidence of explosive reaction in these three tests.

The Henkin Critical Temperature Test is a semi-routine test used to confirm the decomposition kinetic rate parameters determined from differential scanning calorimetry (DSC) measurements. The Henkin Test is useful for a preliminary estimate of scale-up effects even when kinetic parameters are not available. The Henkin sample is larger than the DTA sample, and differences in cook-off temperature are an indication of the direction and magnitude of changes that might occur with even larger samples. The Henkin Test is sometimes called the timeto-explosion test because events often do not occur until several minutes after the sample is placed in a hot bath. The reason for the delay is that there are often induction processes that must occir before the start of the exothermic reactions that cause the event. Rapid gas evolution that moves a gas check or that bursts an aluminum tube is required for an event.

Los Alamos also has an ARC that is used for nonroutine research on explosives. It provides information of special utility for predicting temperatures at which thermal runaway will occur in large samples.

a. Differential Thermal Analysis

(H. H. Cady, J. O. Martinez, B. A. Stine)

In DTA, a sample and an inert reference are heated at a known rate in a controlled environment. The increases in sample and reference temperatures will be about the same (depending somewhat on specific heat and thermal conductivity differences), unless a heat-related change takes 
place in the sample. If such change takes place, the sample temperature either leads (evolves heat) or lags (absorbs heat) the reference temperature. A DTA curve is a plot of the lead or lag as a function of sample temperature.

Two types of DTA machines are used for study of explosives at LANL. One is a DuPont 1090 Thermal Analyzer. It is primarily used for research and is equipped with a 910 cell base and standard Temperature DTA cell. The other DTA was designed at LANL and has been used about 30 years for routine DTA work. Ammonium nitrate samples were tested on both instruments to ensure that the instruments were running properly prior to running the FECN-1 samples.

The DuPont standard Temperature DTA cell was used with a micro-tube silver heating block because this apparatus survives explosions much better than the other available DSC and D'TA cells. The apparatus was operated in the programmed heating-rate mode with sample configuration and equipment settings as recommended by DuPont for their Model 910 Cell Base and standard Temperature DTA Cell. The DTA cell is basically a silver block with a central rod heater. A control thermocouple, used to maintain the programmed heating rate, is located near the heater. Slightly farther from the heater at identical radii are two sample-tube wells. The first well holds a glass capillary $(<2-\mathrm{mm} O D$, 1.5-mm ID) that contains an inert glass-bead sample with its embedded chromel/alumel thermocouple. The other well holds a similar capillary containing the test sample as a tall cylinder with its axial thermocouple. The reference and sample thermocouples are both made from a common lot of thermocouple wire. In operation, the temperature at the center of the test sample is recorded as the $x$-axis, and the temperature difference between the test sample and the glass bead sample is recorded as the y-axis. So many factors influence the magnitude of the difference signal that we rarely use it for any quantitative estimates of heat-of-reaction. On the other hand, the temperatures of deviation from the base line and peak shapes as a function of heating rate do provide useful information. A schematic of the DuPont DTA cell is shown in Figure 5 .

The DuPont 1090 Thermal Analyzer is equipped with a microprocessor, analog-to-digital converters, ruagnetic disk drive, and plotter. Data from a heating experiment are recorded and plotted as the DTA is run. The plot made in real time is seldom optimal, so the recorded data are usually replotted. Figure 6 is a replotted DTA curve where FECN -1 was heated at $10^{\circ} \mathrm{C} / \mathrm{min}$. Figure 7 presents the same data plotted to emphasize the endothermal behavior between 


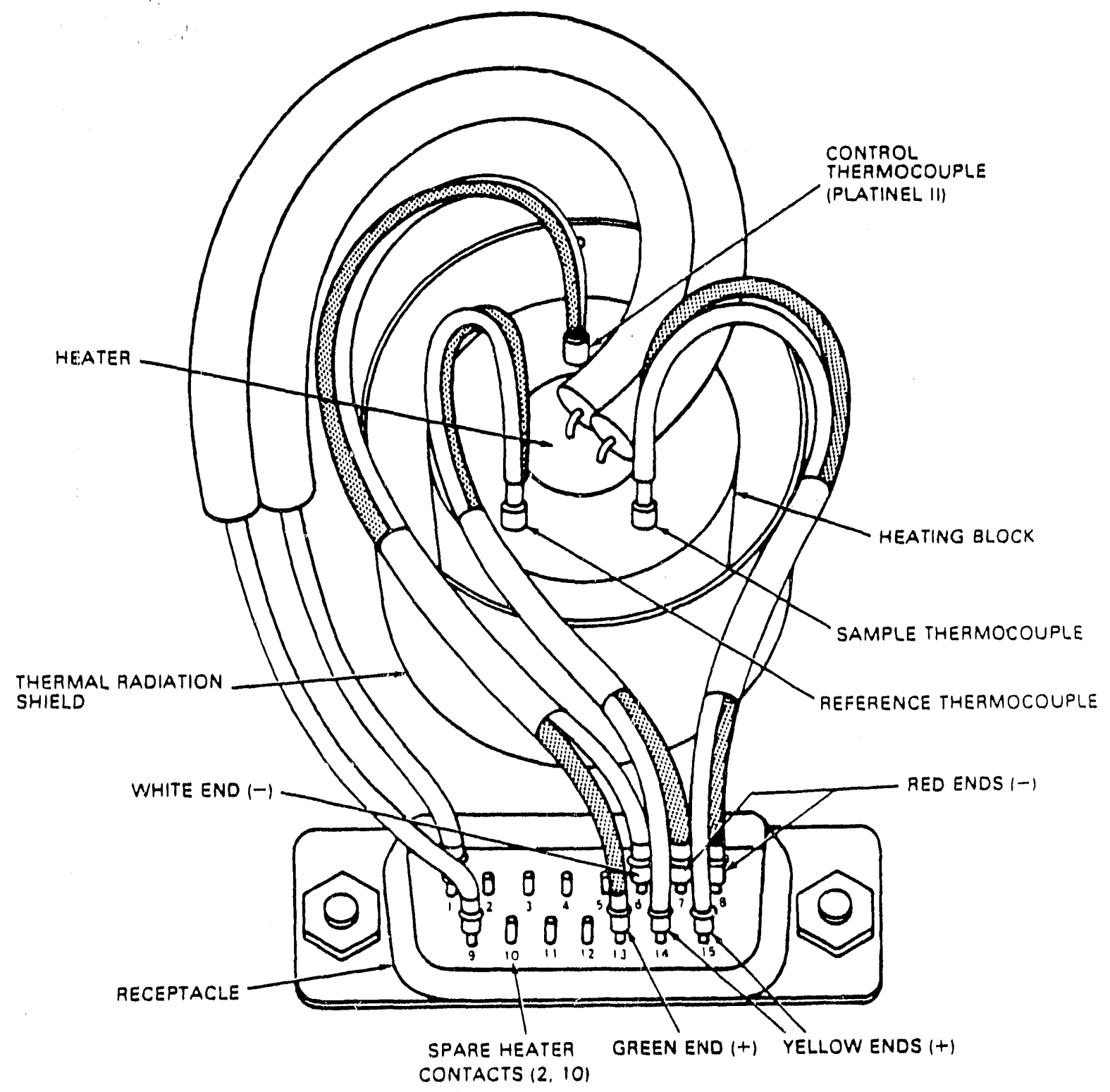

Figure 5. Schematic of DuPont DTA Cell and Thermocouples

$100^{\circ}$ and $240^{\circ} \mathrm{C}$. Three endotherms were observed. We made no attempt to identify the true causes of these endotherms, but water condensed in the cooler parts of the apparatus before $200^{\circ} \mathrm{C}$, so one or both of the first endotherms involved loss of water. International Critical Tables lists the $\mathrm{NaNO}_{2} / \mathrm{NaNO}_{3}$ eutectic as $221^{\circ} \mathrm{C}$, and we agree with PNL's assessment that the third endotherm occurred with the melting of the oxidizer. 


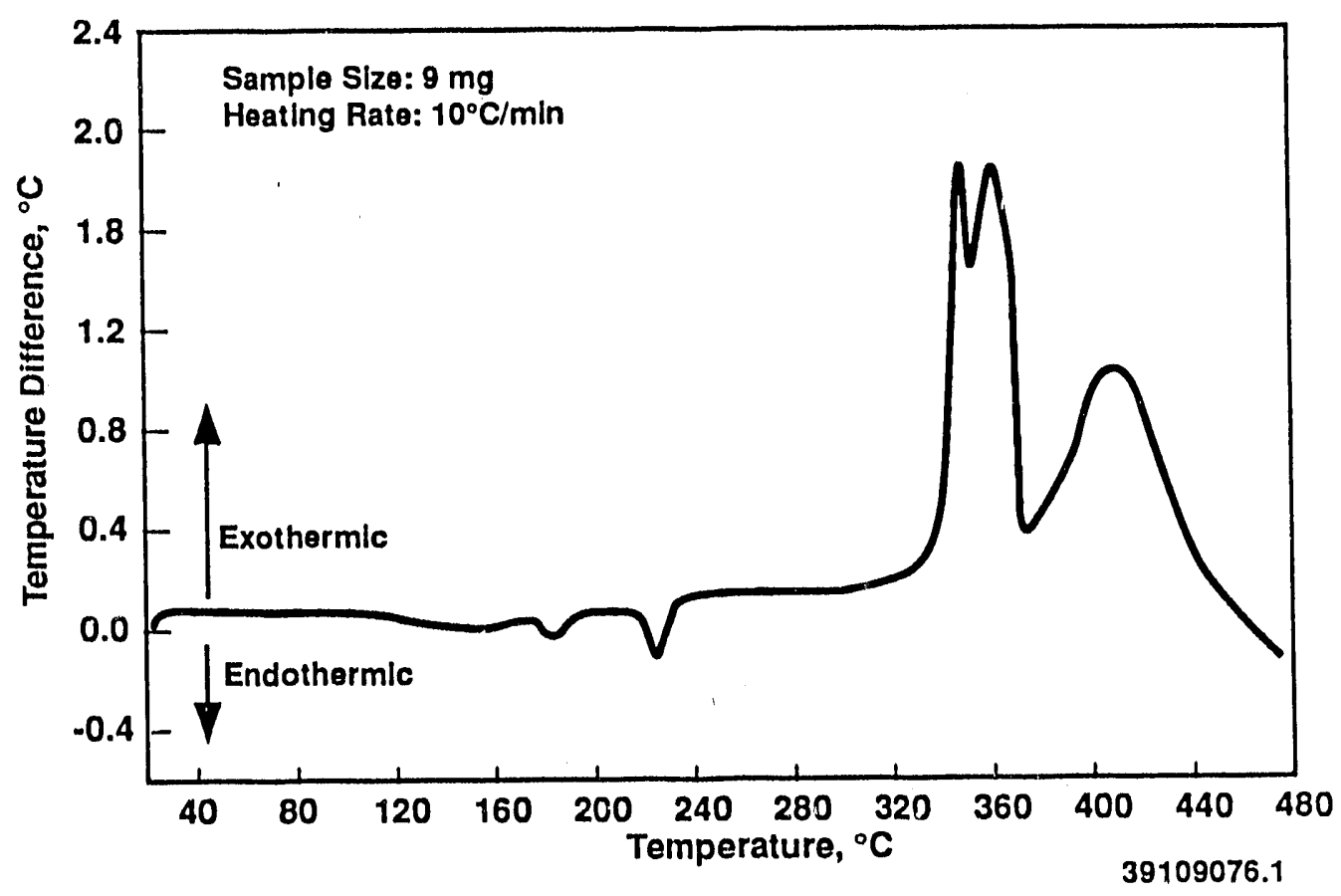

Figure 6. DuPont DTA Curve of FECN-1

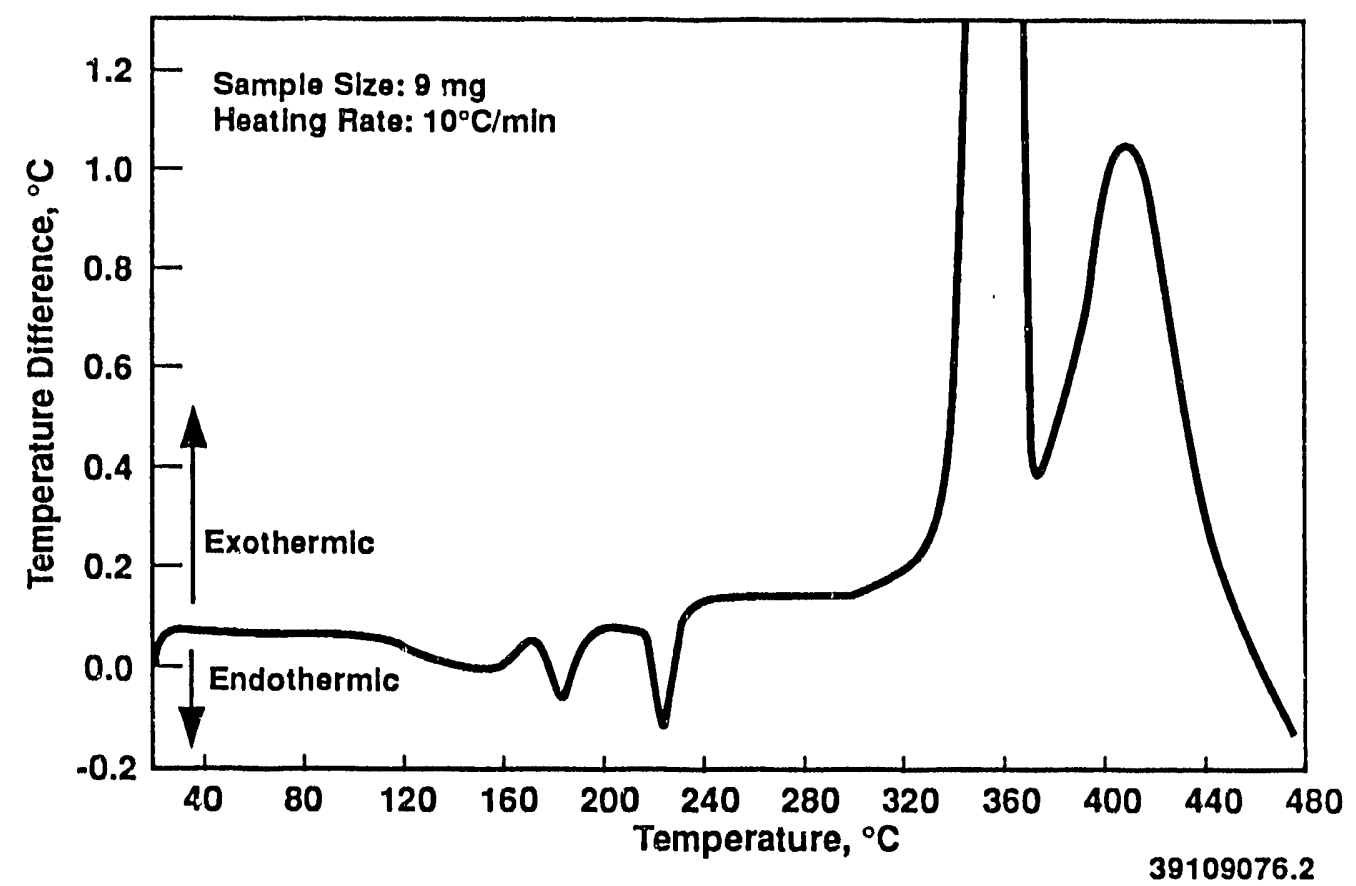

Figure 7. Dupont DTA Curve of FECN-1 Emphasizing Endotherms 
Figure 8 illustrates DTA curves as a function of heating rate. The temperature difference scales were relative and different for each of the four curves. The positions of the endotherms were independent of heating rate, but the positions of the exotherms were not. The exotherms clearly shifted toward lower temperature as the heating rate decreased. This is characteristic of a chemical reaction with an induction process, and the rapid build up in rate, once the exotherm began, looked like a clock reaction. The position of the higher-temperature exotherm was also dependent on heating rate. The most unusual features of the plotted exotherms are the consistency in shape of the two combined exotherms and the consistency of the complex heatevolution behavior at the top of the first exotherm as the heating rate changed. The rate of heat evolution through the first exotherm is not necessarily reproducible, and we have obtained some DTA curves (Figure 9) that resemble the DSC curve furnished by PNL with the FECN-1 sample. The signal-to-noise ratio in our DTA precludes heating rates much slower than $1^{\circ} \mathrm{C} / \mathrm{min}$, but it appears the first exotherm should rapidly liberate heat at temperatures substantially below $300^{\circ} \mathrm{C}$ if a sample is somehow held at an elevated temperature.

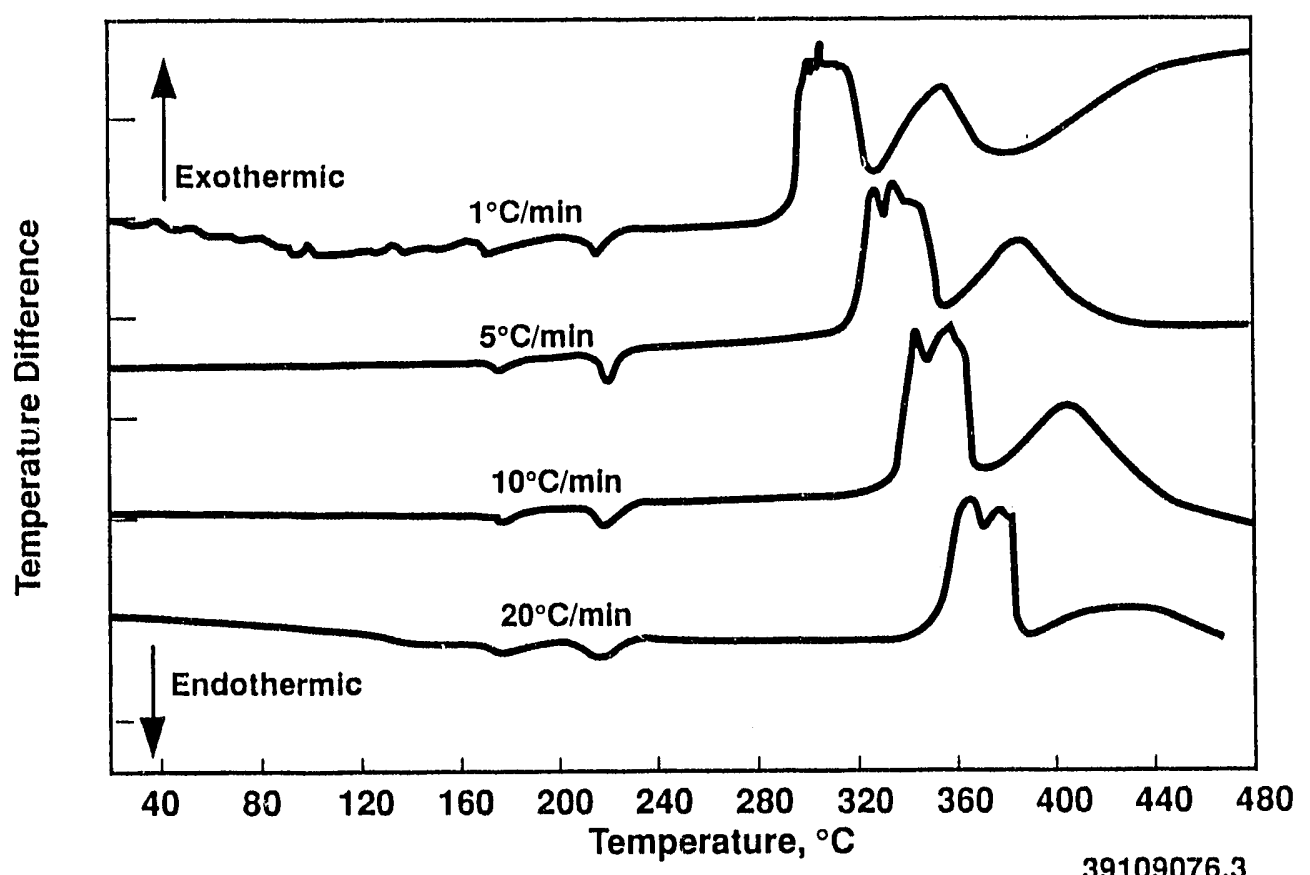

Figure 8. FECN-1 DTA Curves as a Function of Heating Rate 


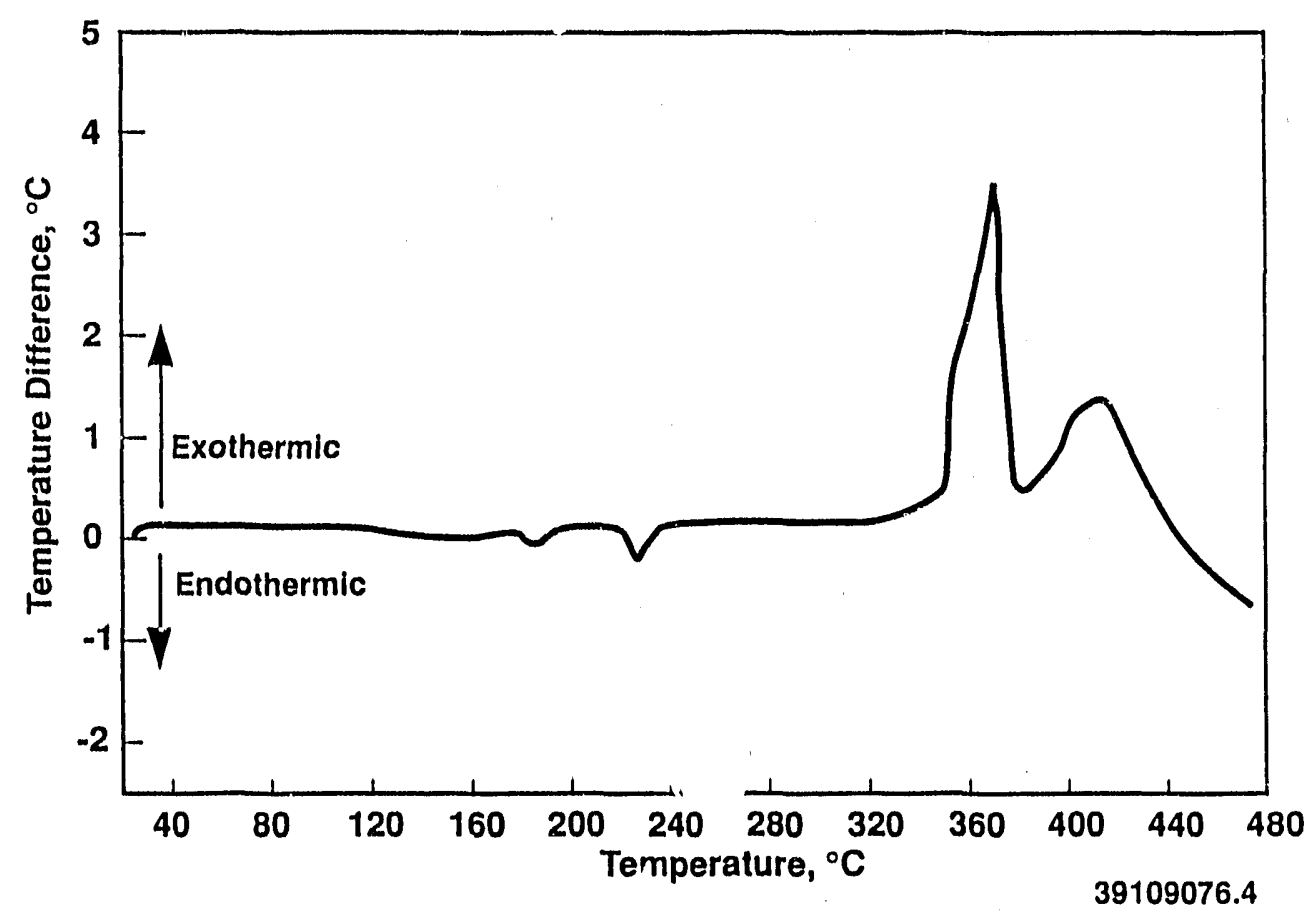

Figure 9. FECN-1 DTA Curve Showing Variation in Exotherm Shape

The LANL routine DTA apparatus differs in several respects from the DuPont DTA. The reference material is sodium chloride instead of glass, and the sample tubes are made of stainless steel instead of glass. A sample tested in the routine DTA is quite different in geometry from the DuPont sample; the shape is a right equant cylinder (height and dianeter measurements are similar). The routine DTA uses a 10-mg sample while the Dupont uses a specified sample volume (a weight of about $9 \mathrm{mg}$ for FECN-1). Also, before testing, the sample for routine DTAs is dried overnight at $60^{\circ} \mathrm{C}$ in a circulating-air oven, while the DuPont tests begin with a sample in equilibrium with ambient air. A schematic of the routine DTA cell is shown in Figure 10.

Routine DTAs were run at one heating rate of $11^{\circ} \mathrm{C} / \mathrm{min}$. A graph with both the routine DTA and pyrolysis curves for FECN-1 is shown in Figure 11. The main difference between the routine and DuPont DTA curves is the change in magnitude of the lowest temperature endotherm. This implies that the lowest endotherm was affected by drying. This lowest temperature endotherm is probably caused by loss of water, and it is associated with the change in weight of FECN-1 with humidity. 


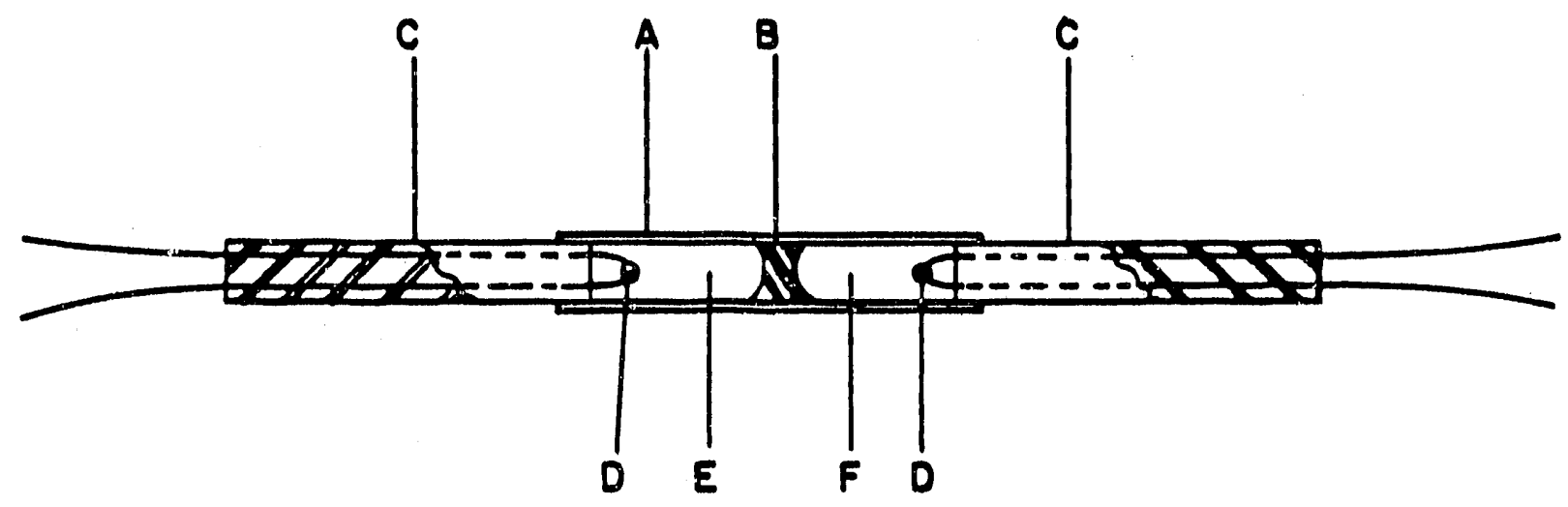
A. Stainless steel Tube
B. Plug
C. Thermocouple Insulator

D. Thermocouple Junction

E. Sample Compartment

F. Reference Compartment

Figure 10. Routine DTA Cell Assembly

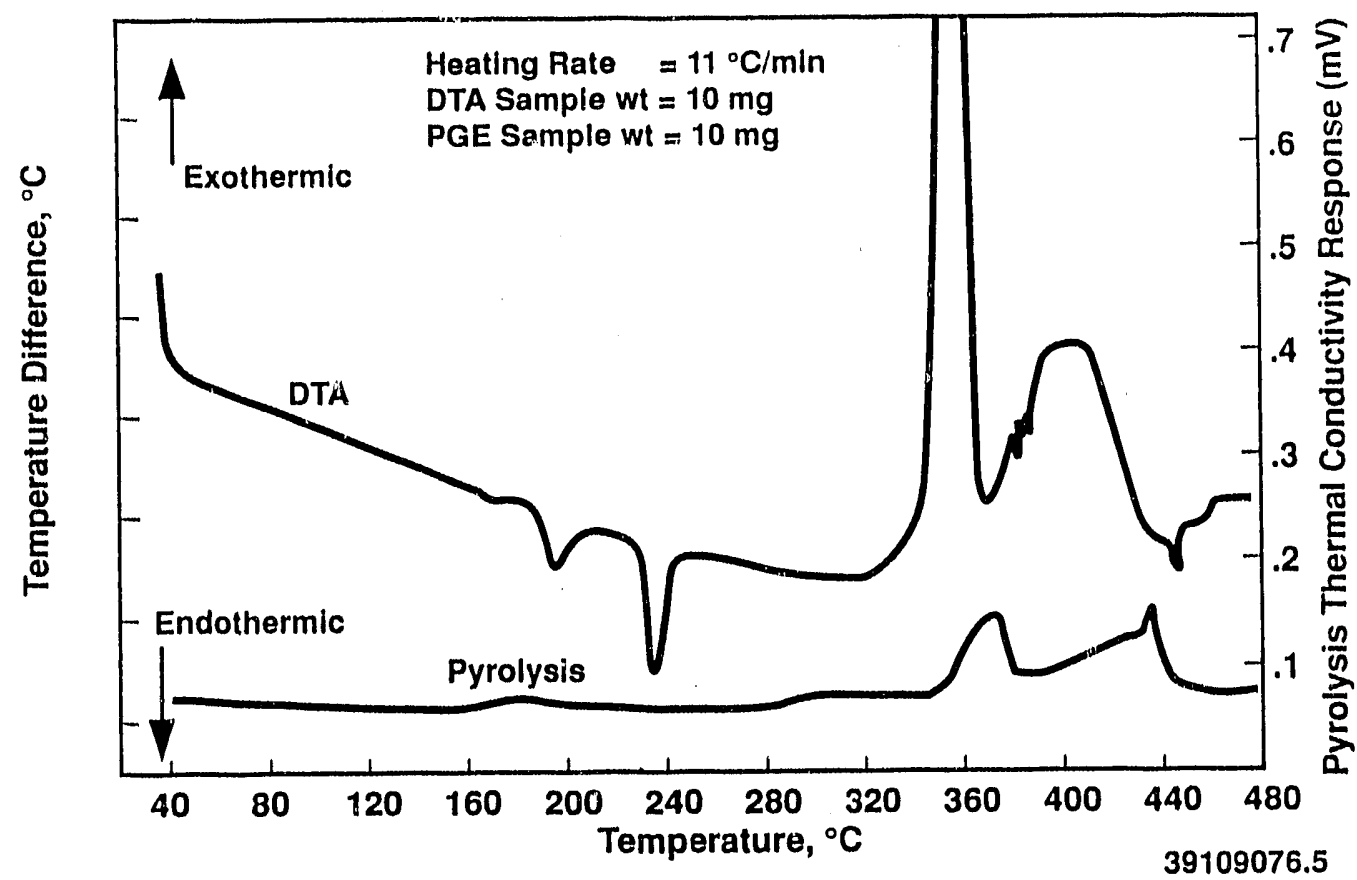

Figure 11. Routine DTA and Pyrolysis Curves for FECN-1

DTA showed that FECN-1 underwent energetic exothermic reactions at temperatures above the eutectic melting point of the $\mathrm{NaNO}_{2} / \mathrm{NaNO}_{3}$ mixture. In our DTAs, these reactions were controlled and did not lead to explosions nor were the 
thermocouples ejected from the cells. This behavior was mild compared with most explosives.

b. Pyrolysis (Gas Evolution as a Function of Temperature) (J. O. Martinez, B. A. Stine)

Pyrolysis tests, which are conducted in a flowing carrier gas stream, have been used for more than 30 years at LANL to study the thermal stabilities of explosives and the compatibilities of various explosive mixtures. DTA and pyrolysis, particularly when used in combination, have to some extent replaced older conventional stability ald compatibility tests.

Pyrolysis curves indicate the rate of gas evolution as a function of temperature. Both DTA and pyrolysis curves are required because thermal transitions do not necessarily imply formation of gaseous products, nor do gaseous products necessarily require detectable thermal reactions. For FECN-1, each curve is determined to the temperature at which decomposition is complete; the range being from room temperature to over $450^{\circ} \mathrm{C}$.

A schematic drawing of the apparatus used to obtain the pyrolysis curves is shown in Figure 12, with details of the pyrolysis block shown in Figure 13. The general procedure for running a sample follows: A sample (about $10 \mathrm{mg}$ ) is weighed and placed in a small combustion boat. The boat is set in the pyrolysis chamber, which is at room temperature. The air in the chamber is then forced out by helium flowing in at a rate of $6 \mathrm{~cm}^{3} / \mathrm{min}$. The temperature of the heliumfilled chamber is then raised at a constant rate of $11^{\circ} \mathrm{C} /$ min. The gases evolved by the sample are carried by the helium stream through the combustion tube and into the thermal conductivity cell, G. The two cells $D$ and $G$ form two arms of a bridge whose output varies with the concentration of impurities (decomposition products, etc.) in the effluent helium stream. The output of the bridge is fed into one input of an $X-Y$ recorder, while the temperature of the pyrolysis block is recorded via the other input of the recorder. In this manner, a curve is directly obtained to show the rate of gas evolution of the sample as a function of temperature.

The purpose of the copper oxide combustion chamber is to convert the more complex products (such as undecomposed but vaporized explosive) to simple molecules. This increases the sensitivity of the bridge and also avoids a troublesome condensation of these products in the cooler portions of the apparatus. 


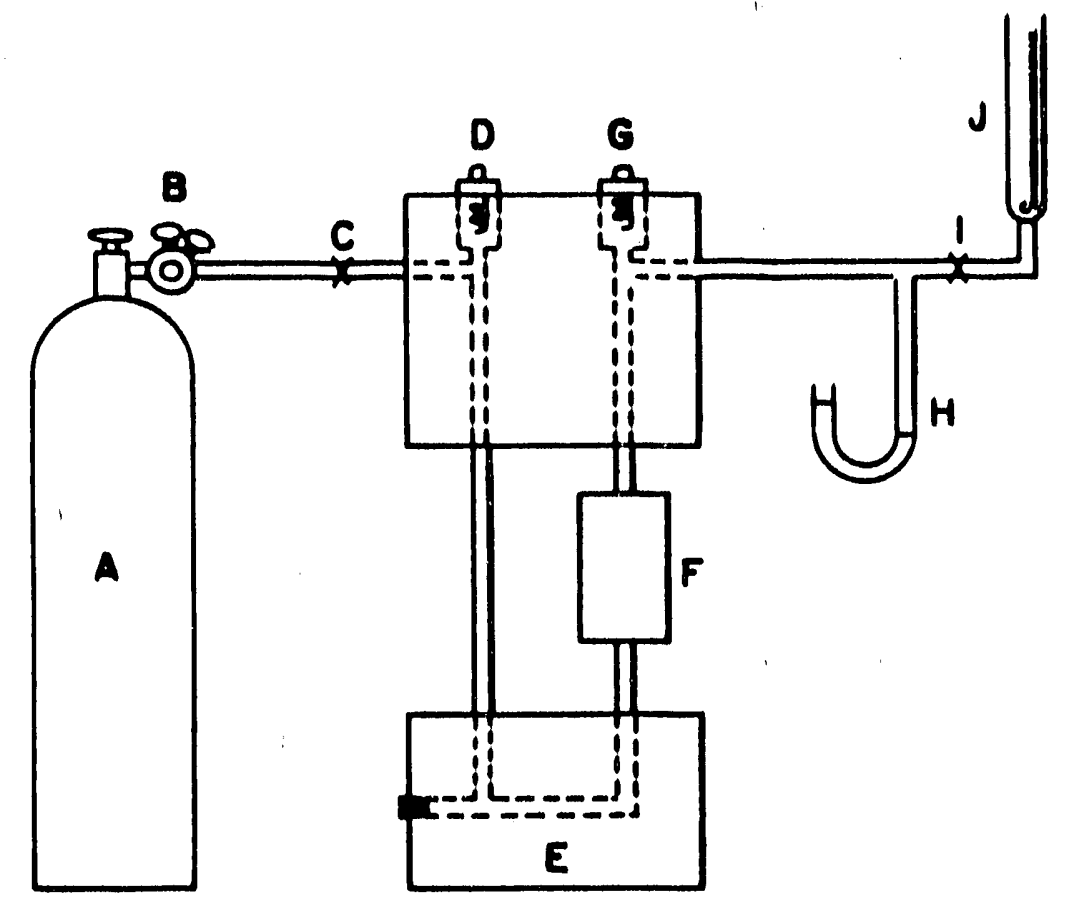
A. Carrier Gas supply
B. Pressure Regulator
C. Flow Control Needle Valve
D. Reference Thermal
Conductivity
E. Pyrolysis Chamber
F. Combustion Tube
G. Active Cell
H. Manometer
I. Pressure Control Needle Valve
J. Ratameter

Fiqure 12. Schematic Drawing of Pyrolysis Apparatus

To ensure that the pyrolysis apparatus was functioning properly, the pyrolysis curve for HMX was determined before FECN-1 was tested. The nearly vertical rise in gas evolution was indicated at $292^{\circ} \mathrm{C}$. This has been the indicated temperature for this apparatus and material since November 1974 when the position of the recording thermocouple was moved from the block below the sample into the flowing helium stream. The indicated temperature is about $12^{\circ} \mathrm{C}$ higher than that of the actual HMX sample. Most of this error is caused by the heat capacity of the sample and boat being much greater than the thermocouple. In any event, the pyrolysis curve is indicated to be about $12^{\circ} \mathrm{C}$ higher than the actual temperature. 


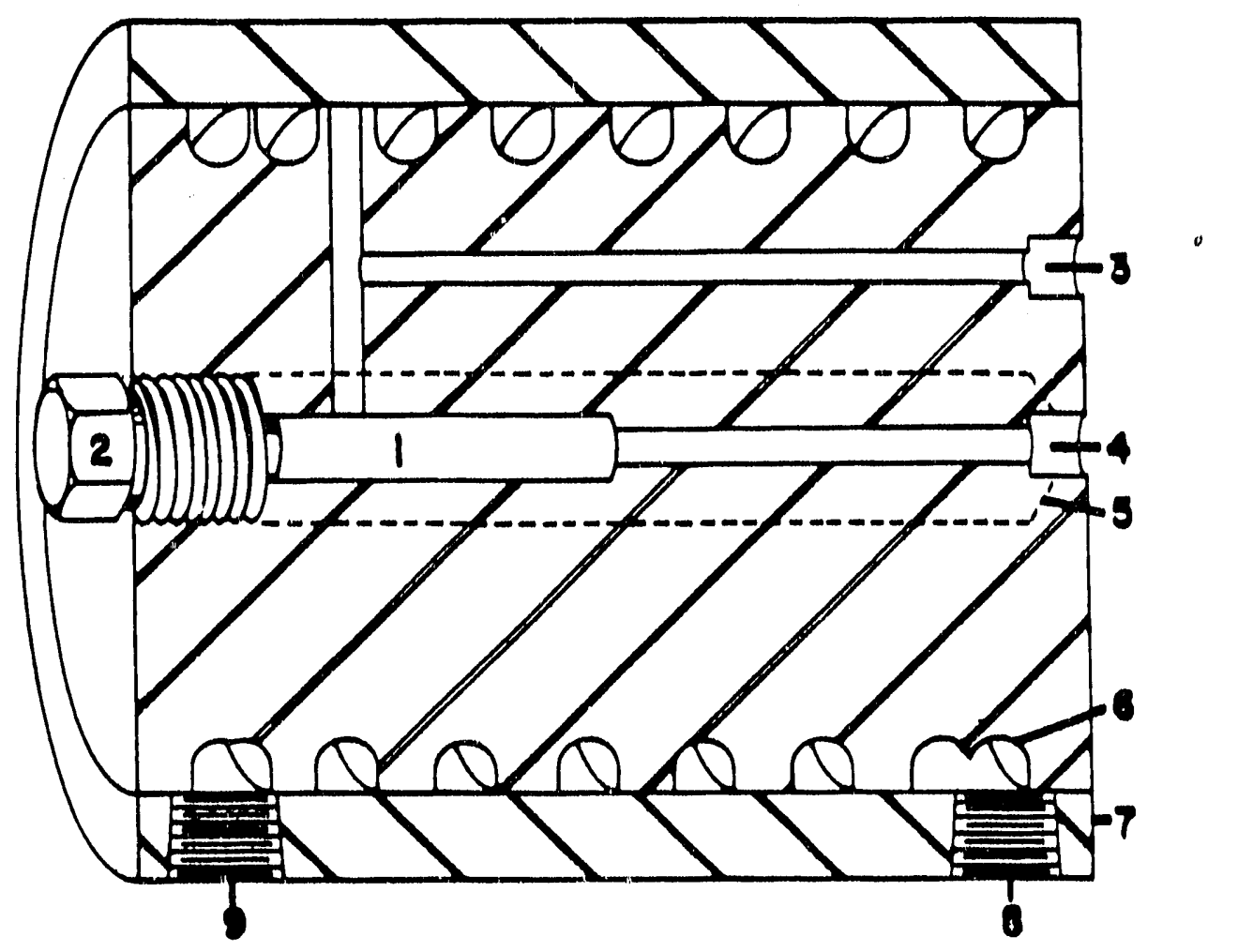

1. Pyrolysis Chamber

2. Nickel Plug

3. Carrier Gas Inlet

4. Carrier Gas outlet

5. Cartridge Heater Wells
6. Helical Threads Cut in Inner Body of Block

7. Outer shell of Block

8. Cooling Jacket Inlet

9. Cooling Jacket outlet

Figure 13. Pyrolysis Block

The pyrolysis curve is shown in Figure 11. The pyrolysis peak, with a $380^{\circ} \mathrm{C}$ maximum, coincides with the DTA peak that is off scale at $360^{\circ} \mathrm{C}$. There are four significant peaks in gas evolution. The first one, with a corrected temperature between $150^{\circ}$ and $190^{\circ} \mathrm{C}$, is probably caused by loss of water of hydration. The second peak, which is small, occurred between $270^{\circ}$ and $330^{\circ} \mathrm{C}$ and slightly precedes the beginning of the first exotherm; it is not assoclated with any recognizable thermal event. The third peak, which is well-.defined at a corrected temperature of $368^{\circ} \mathrm{C}$, is associated with the lowest temperature exotherm. The final gas evolution peak, which reaches a maximum at $436^{\circ} \mathrm{C}$, seems to be associated with the tail and not the peak of the second exotherm. This association means that the second exotherm cannot be caused by a simple chemical reaction. 
c. Vacuum Thermal stablilty (Gas Evolution on Thermal Aging) (J. O. Martinez, B. A. stine)

The Vacuum Thermal stability (VTS) test has long been used in the explosives industry as a primary indicator of chemical stability and compatibility of mixtures at processing temperatures. The function of the test is to look for evidence of chemical reactions that liberate permanent gases at temperatures at the upper limit of temperatures used to process explosives. Steam is the heat source most common for processing explosives, and $120^{\circ} \mathrm{C}$ is the normal maximum temperature for the steam pressures allowed at: LANL. The routine VTS test at LANL measures gas evolved at $120^{\circ} \mathrm{C}$ over a 48-h pertod. The VTS test is required before energetic materials are allowed in the LANL explosives processing area even when reactivity is not expected.

Figure 14 is a photograph of the VTS marometer tube and sample tube. Historically, a sample of material was sealed in a test bulb and attached to a manometer tube, which was then evacuated; a small amount of mercury was added to seal the sample from ambient atmosphere. The test bulb with sample was inserted into an oil bath of known temperature. After equilibration, mercury column height, room and bath temperature, and barometric measurements were taken for starting conditions and converted to give gas volume at standard temperature and pressure (STP). The test bulb with sample remained in the hot oll bath for a period of time during which the material could partially decompose. Any evolved gas would change the height of the mercury in the manometer. After the test was completed, the final height, temperatures, and barometric pressure were again measured, and another STP volume was determined. The amount of gas evolved was calculated as the difference between the starting and final volumes. The apparatus used at LANL continuously and automatically monitored the parameters needed to calculate STP volume. Gas evolution was reported hourly throughout the test.

Two innovations make the VTS anenable to electronic monitoring. First, the manometer tube is incorporated as a capacitance transducer into a circuit that generates a voltage as a function of the height of the mercury column. The second innovation is an air back-pressure system by which the mercury column can be raised precisely by an adjustable pressure reduction valve so that the calibration of the voltage as a function of the height of the mercury column can be accomplished in situ. This same device provides a constant $760-\mathrm{mm}$ Hg pressure to the manometer Hg pool during a test run. 
(9)

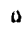

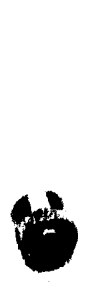

"

s.

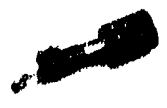

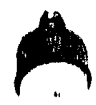

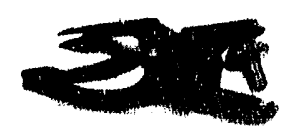

Figure 14. VTS Manometer Tube and Cell

A. 24 
other quantities are needed to make the gas volume calculation. The volumes of the sample tube and the manometer tube as functions of mercury level are required. These are obtained by welght of the tubes when empty and filled approprtately with mercury. The manometer is constructed of true-bore glass tubing so that volume is a constant function of mercury height in the region of measurement. Gas evolutions are normalized to $\mathrm{cm}^{3} / 9$ for 48 h by dividing the measured gas volume by the sample welght.

Proper operation of the VTS apparatus was ensured by running 900-10 inert, a standard known material, conourrently with the FECN-1 sample. The apparatus functioned normally; the test results for 900-10 were also normal. The computer printout summaries for the FECN-1 and 900-10 explosiveinert standard are shown in Figures 15 a and $b$. Table 5 summarizes the results for FECN-1, the sample of 900-10, and the average for the past ten runs on the 900-10 inert. Table 5 also lists several conventional explosives.

As can be seen, FECN-1 evolved less gas than the conventional explosives. This amount of gas is essentialiy background, and the sample did not react detectably to give permanent gases at $120^{\circ} \mathrm{C}$. Water condensation in the cooler

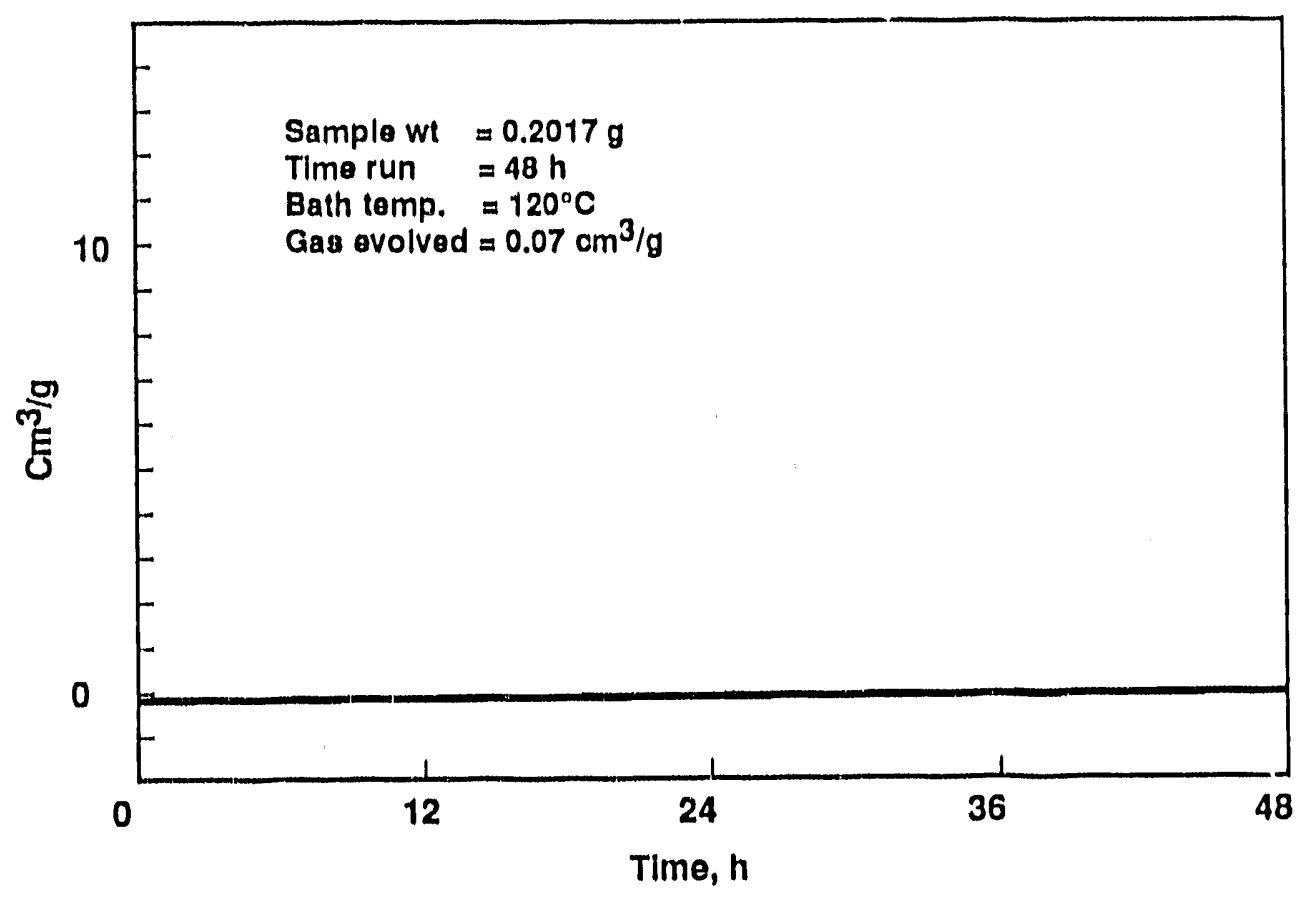

Figure 15a. VTS Gas Evolution for FECN-1 


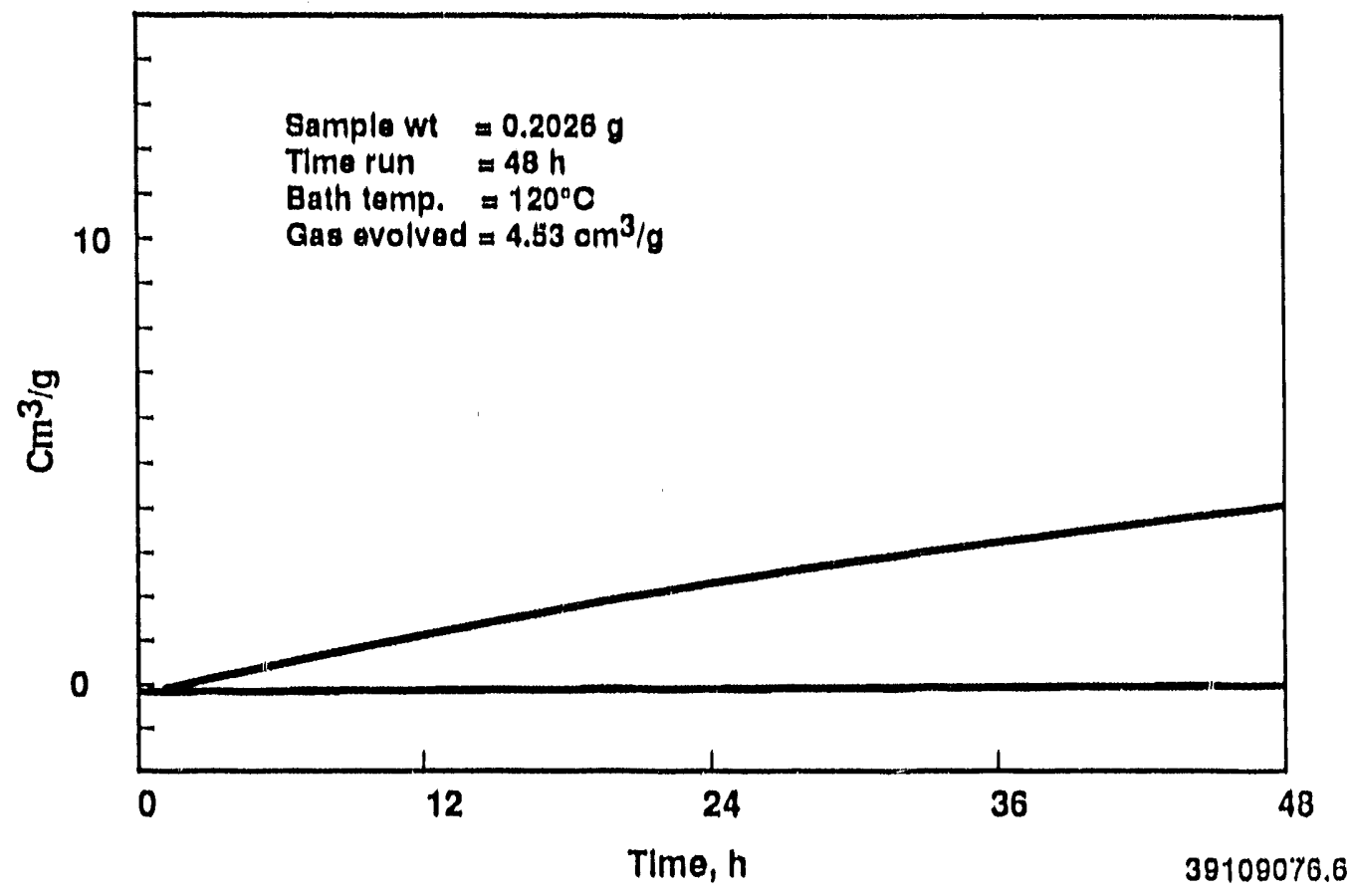

Figure 15b. VTS Gas Evolution for 900-10 Inert

Table 5. Vacuum Thermal stability

Sample

FECN - 1

900-10 Inert

900-10 average

$\operatorname{PETN}\left(100^{\circ} \mathrm{C}\right)$

RDX

HMX

TNT

TATB

$$
\begin{array}{r}
\text { Gas Evolution at } 120^{\circ} \mathrm{C} \\
(\mathrm{ml} / \mathrm{g} / 48 \mathrm{~h})
\end{array}
$$

$$
0.07
$$

4.53

$4.8 \pm 0.2$

0.2 to 0.5

0.1 to 0.3

0.1 to 0.4

0.2

0.0 to 0.2

parts of the manometer tube during the run was noted. Condensation meant that the sample evolved water, although the test does not detect condensible gases.

c. Henkin Critical Temperature (Time-to-Explosion) (M. M. Stineaipher)

All explosives and many other materials decompose exothermically at temperatures above absolute zero. When gas producing chemical decomposition produces heat faster than 
It can be dissipated to the surroundings, the explosive mass self-heats to explosion. In steady-state conditions, the lowest temperature at which a thermal explosion is produced is called the critical temperature, Tm. A relatively simple expression has been derived in terms of the kinetic and physical parameters.

$$
\operatorname{Tm}:=\frac{E}{R \cdot \ln \left[\frac{A^{2} \cdot \rho \cdot Q \cdot Z \cdot E}{\mathrm{Tm}^{2} \cdot \lambda \cdot \delta \cdot R}\right]}
$$

where $R=$ Gas constant, $1.987 \mathrm{cal} / \mathrm{mol} / \mathrm{K}$

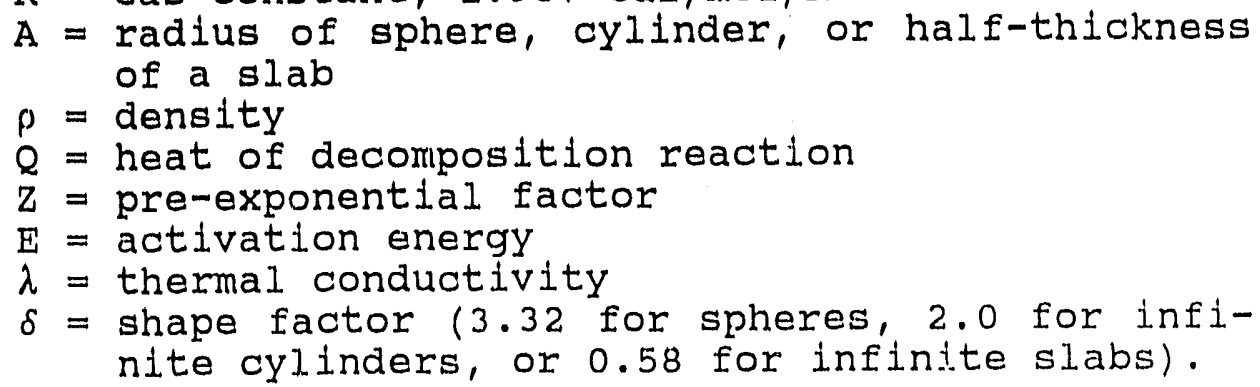

The LANL method for determining critical temperatures is based on a time-to-explosion by developed Henkin. The explosive, usually $40 \mathrm{mg}$, is pressed into a DuPont E-83 aluminum blasting cap shell and covered with a hollow, aluminum, skirted plug. A conical punch is used to expand the plug and apply a reproducible 400-1b force. This plug expansion forms a positive seal and confines the sample in a known geometry. The density, which can be calculated from the sample weight and a sample thickness measurement, is usually about $90 \%$ of the crystal density.

This assembly is placed into a preheated liquid metal bath, and the time-to-explosion is measured as the time to the sound (or rapid movement of the plug) created by the rupture of the blasting cap or the unseating of the plug. The lowest temperature at which a runaway reaction can be obtained is the $\mathrm{Tm}$. Many tests are required to confidentially determine $\mathrm{Tm}$ because $i t$ is necessary to raise and lower the bath temperature across the apparent $\mathrm{Tm}$, perform many separate tests, and allow enough time for a reaction. A "safe" criterion for $40-\mathrm{mg}$ samples is no explosion in 1000 seconds. We have never obtained an explosion after 10,000 seconds. 
Because the reactions can be violent, we use the metal-bath enclosure shown in Figure 16. The baffles contain most of the hot metal in the chamber, and the test can be conducted behind a shield in a fume hood.

Proper operation of the Henkin Critical Temperature apparatus was ensured by running a standard sample of HMX (1 ot BGW Q584) and determining its critical temperature. The uncorrected-temperature, time-to-explosion data are shown in Figure 17. The corrected measured value of $256^{\circ} \mathrm{C}$ is normal for this sample of UK HMX; it is higher than the value $253^{\circ} \mathrm{C}$ for normal production grades of HMX.

The uncorrected-temperature, time-to-explosion data for FECN-1 are shown in Figure 18. After temperature correction, the critical temperature is $367^{\circ} \mathrm{C}$. The Henkin Critical Temperatures for the HMX standard, FECN-1, and several standard explosives are reported in Table 6 .

The Tm of FECN-1 is slightly higher than that of TATB. It must be remembered that these data reflect only one point on a critical temperature versus sample--thickness curve, and represent a very thin sample from which heat is easily removed by thermal conduction. Explosion temperatures for all these materials will be substantially lower for large

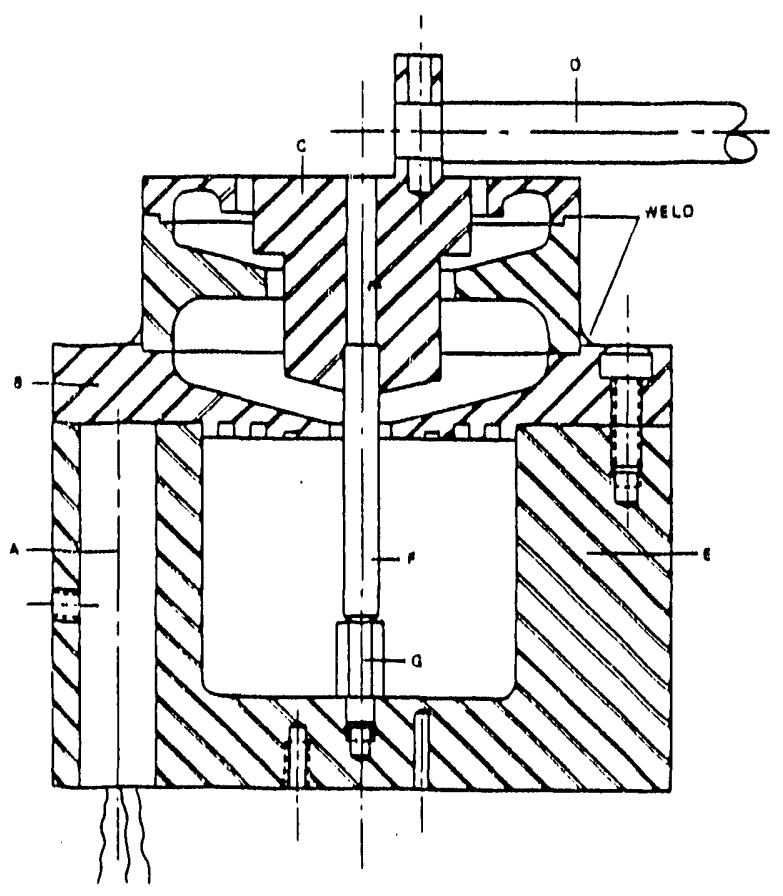

A. Cartridge heaters (3 each)

B. Top assembly, bolted to bese

C. Sample-cell holder (the sam. ple cell is insulated from the holder by a band of glass tape around its top)

D. Sample.cell holder pivot arm, which allows cell and holder to be inserted remote. ly into the lower assembly

E. Metal-bath container, made from mild steel for stability when containing molten metal

F. Sample cell

G. Sample cell support pedestal, whose length is ad. justed to the sample cell length

Figure 16. Henkin Test Metal-Bath Assembly 


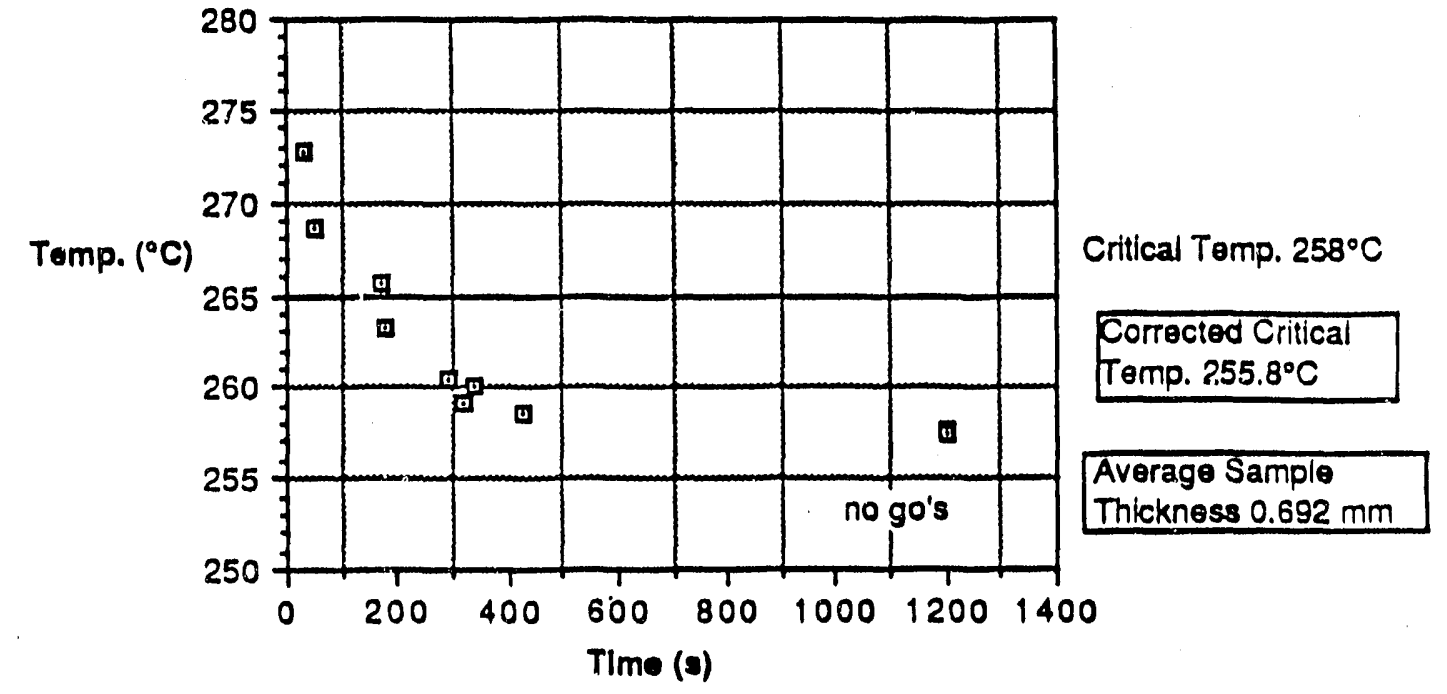

Figure 17. Henkin Time-to-Explosion Data for HMX BGW Q584

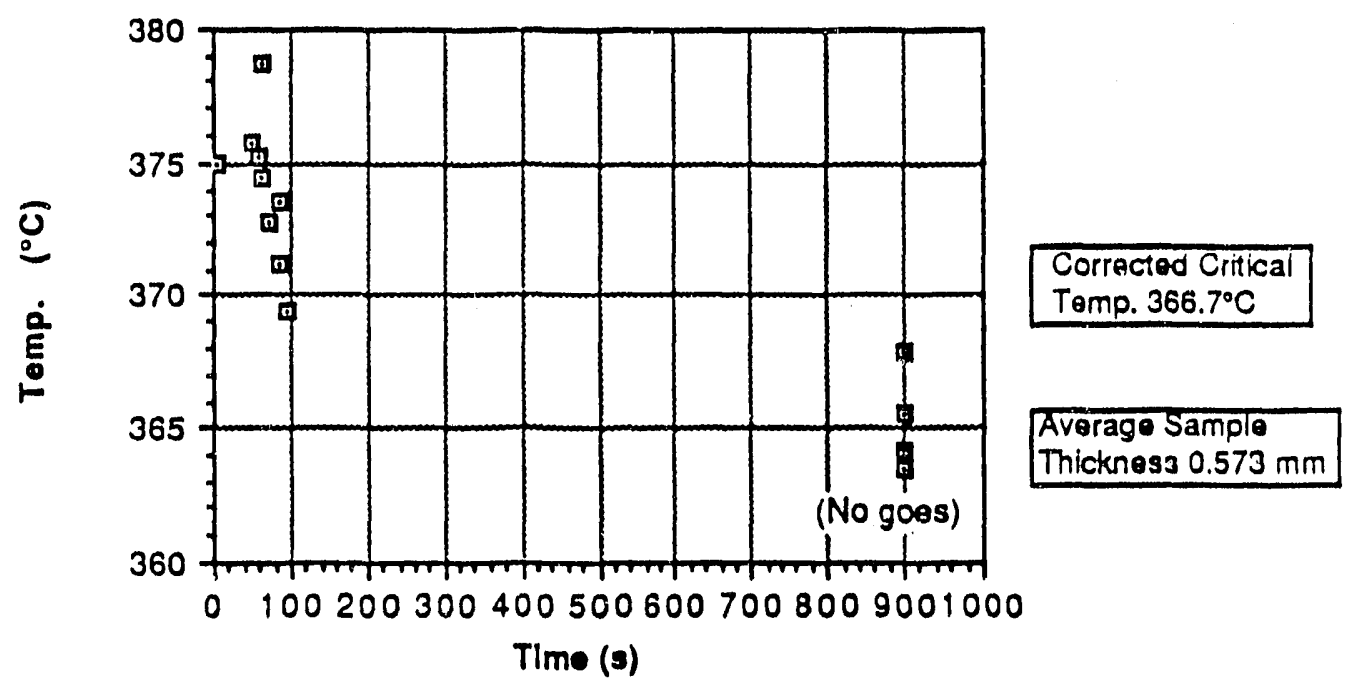

Figure 18. Henkin Time-to-Explosion Data for FECN-1

masses of material. Note that for these materials the critical temperature is near or below the pyrolysis peak for gas evolution. Induction processes are important when the Henkin temperature differs substantially from the pyrolysis temperature. Because of differences in cell materials, sample geometry, density, and thermal conductivity, there is no reason to suppose our result for $\mathrm{FECN}-1$ contradicts the temperature $\left(333^{\circ} \mathrm{C}\right)$ reported to us of a similar type of experiment by PNL. 
Table 6. Henkin Critical Temperature

\begin{tabular}{|c|c|c|c|}
\hline Material & $\begin{array}{c}\mathrm{Tm} \\
\left({ }^{\circ} \mathrm{C}\right) \\
\end{array}$ & $\begin{array}{c}a \\
(\mathrm{~mm})\end{array}$ & $\begin{array}{l}\text { Pyrolysis } \\
\left.\text { Peak ( }{ }^{\circ} \mathrm{C}\right)\end{array}$ \\
\hline HMX (BGW Q584) & 256 & 0.35 & $\sim 285$ \\
\hline FECN-1 & 367 & 0.29 & $\sim 365$ \\
\hline PETN & 192 & 0.34 & $\sim 190$ \\
\hline RDX & 216 & 0.35 & $\sim 215$ \\
\hline HMX (Rex UK) & 257 & 0.33 & $\sim 285$ \\
\hline TNT & 286 & 0.38 & $\sim 290$ \\
\hline TATB (purified) & 353 & 0.33 & 400 \\
\hline
\end{tabular}

d. Accelerating Rate Calorimetry (ARC)

(M. M. Stinecipher)

The Columbia Scientific Industries ARC at LANL is our most sensitive apparatus for studying heat evolved from reacting materials.

The ARC is an analyzer for hazard evaluation of exothermic reactive chemicals. Its primary function is to maintain a sample and its cell in an adiabatic state and permit the sample to undergo thermal decomposition due to self-heating while recording the time-temperature relationship for a runaway process.

The key objective in ARC design and construction is the maintenance of near perfect adiabatic conditions. To accomplish this, the sample cell is placed inside a nickelplated, copper jacket equipped with strategically located thermocouples and heating elements to produce a uniform jacket temperature and a sample cell to jacket temperature difference of zero.

Although the sample, cell, and jacket are all that is theoretically necessary to carry out a measurement, the length of the run may be months, years, or more if begun under ambient conditions. Therefore, the ARC is equipped with a radiant heater that is used to step the sample temperature up to a level where the self-heat rate is such that the run duration is acceptable.

once a self-heat rate is detected, as evidenced by a slow, steady temperature increase, the sample is left adiabatic to complete its thermal spiral. From recorded data for the experimental system of sample plus cell, one can measure:

- time/temperature runaway curve

- adiabatic temperature rise

\section{A. 30}


- temperature of maximum rate

- time-to-maximum rate,

- self-heat rate at any temperature.

From these data it is possible to predict the behavior of the isolated chemical as well as the behavior of the chemical in other systems (e.g., drums, tank cars, and process equipment). These results assist in making an accurate hazard prediction of the reactive chemical. In addition, the various kinetic parameters that describe the decomposition reaction may be studied.

The ARC is fully automated and requires minimal operator attention during a run. The system consists of the adiabatic calorimeter, containment vessel, jacket heater power supply and interface, central control microprocessor unit, and recorder for data plots. Figure 19 illustrates the internal logic and control schematic of the ARC microprocessor system.

The logic used to search for and follow an exotherm is programmed to permit user selection of run parameters and to provide display of critical variables such as time and temperature. The search for a reaction exotherm is accomplished by elevating the sample temperature by a fixed increment (step heat), then checking to see if the selfheat rate exceeds a user-selectable threshold $\left(0.01^{\circ} \mathrm{C} / \mathrm{min}\right.$ for $\mathrm{FECN}-1$ ). Once an exotherm is detected, automatic collections of time and temperature data are carried out until the self-heat rate has dropped back below the threshold value. This will occur when the reaction is finished, or it can occur when an endothermic reaction, such as a phase change, is encountered. Figure 20 illustrates a typical run sequence used to detect and follow an exothermic runaway reaction.

The microprocessor provides continuous control of the temperature difference between the sample and three separate zones of the calorimeter jacket (top, side, and bottom) for adiabatic conditions. Sample and jacket thermocouple inputs, span, and zero reference voltages are multiplexed through a voltage-to-frequency converter circuit to provide stable, low-noise operation. At low self-heat rates, further filtering of thermocouple inputs is achieved by time averaging of signals.

A Kaye ice point references the thermocouples to $0.0^{\circ} \mathrm{C}$ for accurate and stable temperature measurement. The ice point is stable to within $0.01^{\circ} \mathrm{C}$. Electronic cold junction compensation is not suitable for use with the ARC. 


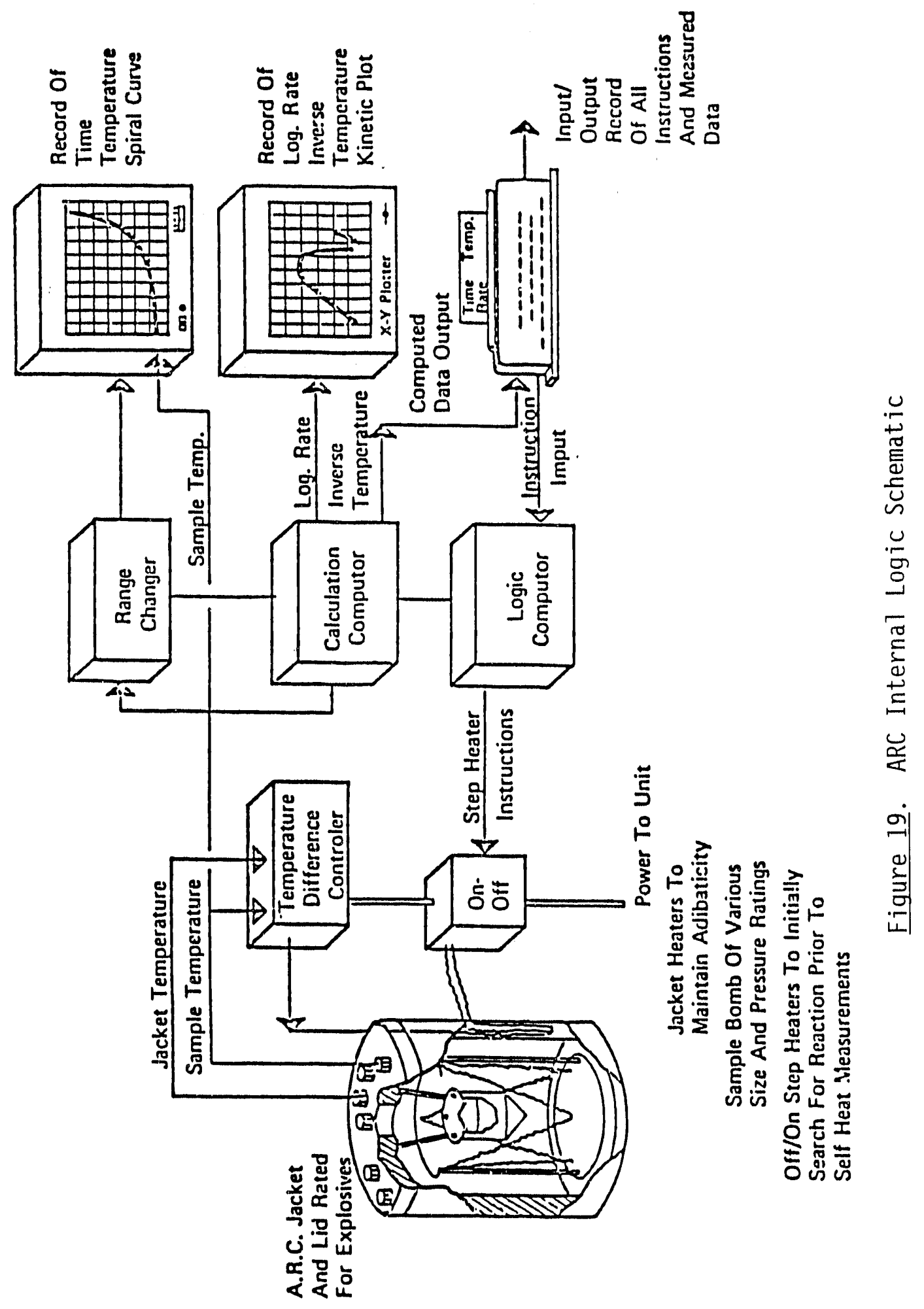

ล. 32 


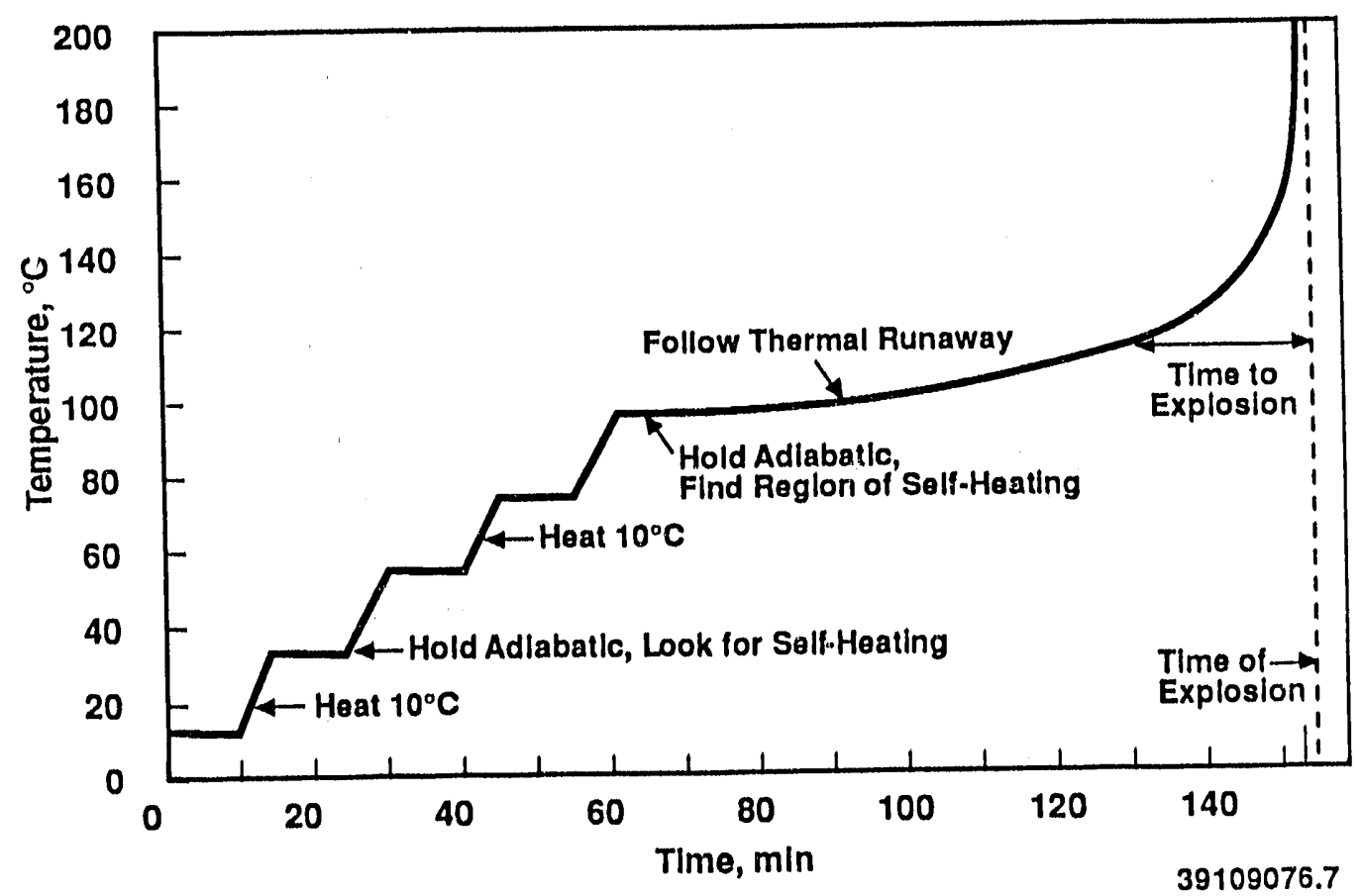

Figure 20. Typical ARC step Run with Exothermic Reaction

Figure 21 illustrates the calorimeter and sample cell. The calorimeter package consists of an insulated aluminum canister that houses the calorimeter jacket, and sample cell assembly, and provides connections for thermocouples, heating elements, pressure transducer, and jacket cooling air. This calorimeter package is mounted inside a rugged vessel for containment of pressure in the event of a ruptured sample cell and for venting of toxic gases that may be produced during a run. Experience has shown that the calorimeter package and rugged vessel can easily sustain the rupture of a sample cell. However, the calorimeter package can essentially be destroyed by the explosion of $5 \mathrm{~g}$ of HMX; therefore, we operate with $0.5-\mathrm{g}$ samples to prevent excessive damage to the calorimeter.

The calorimeter jacket is constructed of nickel-plated copper. This composition limits operation of the calorimeter to about $400^{\circ} \mathrm{C}$ to prevent degradation by igh temperature oxidation. The jacket is divided int three zones: top, side, and bottom. The temperature of each zone is independently controlled by a thermocouple that detects average temperature. The calorimeter heaters have sufficient capacity to raise the calorimeter-jacket temperature at a rate of $15^{\circ} \mathrm{C} / \mathrm{min}$. The inside thermocouple indicated in Figure 21 is not used. 


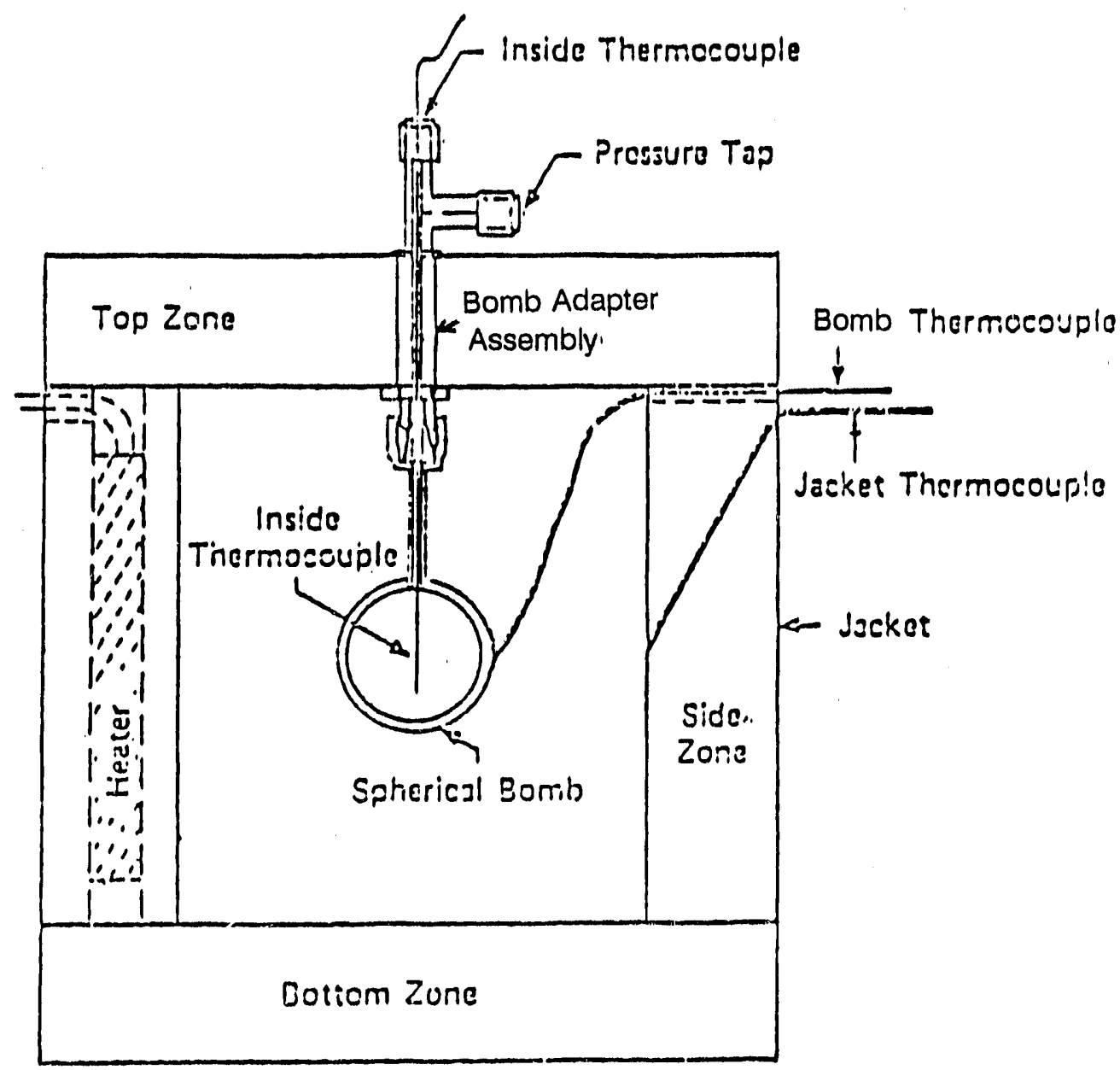

Figure 21. ARC Calorimeter Package and Sample Cell

The sample cell is constructed of corrosion-resistant Hastelloy C. At the tops of the cells, we replace the Swagelok fittings with cajun fittings for a better seal. stainless steel gas seals are used to confine reaction products to the sample cell while the measurements of interest are taken.

The sample-cell temperature is measured by a thermocouple clamped directly on the outside surface of the cell. At high self-heat rates of a reacting sample, the sample temperature may be substantially higher than the surface of the cell. This condition only occurs shortly before an actual explosion and is not particularly important for hazard assessment. Hazard prediction depends almost exclusively on the lower or initiation part of the reaction. 
Also, at high self-heat rates the calorimeter-jacket temperature cannot be raised fast enough to maintain adiabatic conditions.

We use a two-pen, multiple-span, strip-chart recorder to monitor ARC experiments. Full-scale range is $10^{\circ} \mathrm{C}$. One pen records actual sample temperature, and the other pen records the difference in temperature between the cell and the calorimeter jacket.

Proper operation of the ARC was ensured by performing a calibration run on an empty sample cell to check that the actual temperature drift of the sample cell was zero or slightly negative (but no more than $-0.005^{\circ} \mathrm{C} / \mathrm{min}$ ) for all temperatures between $50^{\circ}$ and $450^{\circ} \mathrm{C}$. A sample of HMX (BGW Q528) was then run in the step mode starting at $50^{\circ} \mathrm{C}$ with $10^{\circ} \mathrm{C}$ steps. After each step, $10 \mathrm{~min}$ was allowed for the calorimeter to equilibrate, and then $20 \mathrm{~min}$ was used to test for an exothermic reaction. If an exothermic reaction was not detected within $20 \mathrm{~min}$, the step was repeated.

The data showed an endothermic reaction while the ARC was testing for reaction at $179^{\circ} \mathrm{C}$ (corrected temperature). This was caused by the HMX-I-to-HMX-II phase transition. After the steps to $189^{\circ}, 199^{\circ}$, and $209^{\circ} \mathrm{C}$, there was evidence an of exothermic reaction insufficient to trigger a change in mode for the ARC. A rapid exotherm started after the step to $219^{\circ} \mathrm{C}$, and the cell temperature rose to $235^{\circ} \mathrm{C}$ over the next $72 \mathrm{~min}$. At that point, the calorimeter lost control, and the temperature rose to $400^{\circ} \mathrm{C}$ within $10 \mathrm{~min}$, terminating the experiment. The sample cell did not rupture; this was desirable because the calorimeter was not subject to damage. The ARC was operating as expected with an energetic material.

FECN-1 ARC Experiment 1

A $0.4745-g$ sample of $\mathrm{FECN}^{-1}$ in a light-weight Hastelloy $\mathrm{C}$ cell (LHC) was analyzed from $50^{\circ}$ to $455^{\circ} \mathrm{C}$ in $10^{\circ} \mathrm{C}$ steps. A 10-min wait and a 20-min search for an exothermic reaction followed each step. If a heat rise of $0.01^{\circ} \mathrm{C} / \mathrm{min}$ or greater was found, then the calorimeter switched to the adiabatic mode and stayed in the adiabatic mode until the rate of heat rise fell below $0.01^{\circ} \mathrm{C} / \mathrm{min}$. The calorimeter would then return to the step mode and step $10^{\circ} \mathrm{C}$ from its current temperature. The ARC showed an endotherm after the step to $179^{\circ} \mathrm{C}$ (corrected temperature). An exotherm insufficient to switch the ARC to the adiabatic mode was observed at $209^{\circ} \mathrm{C}$. At $219^{\circ} \mathrm{C}$, an exotherm was detected. The calorimeter followed this exotherm for $1.5^{\circ} \mathrm{C}$ over a time of 104 min before switching back to the step mode. 
The calorimeter indicated exothermic reaction too weak to switch to adiabatio at $230^{\circ}$ and $240^{\circ} \mathrm{C}$ (note, the DTA shows an endothermic reaction from $218^{\circ}$ to $240^{\circ} \mathrm{C}$ ).

The interpretation is that the exothermic heat of chemical reaction was nearly cancelled by the endothermic heat of melting of the $\mathrm{NaNO}_{2} / \mathrm{NaNO}_{3}$ eutectic. At $250^{\circ} \mathrm{C}$, the calorimeter recognized an exotherm and switched to its adiabatic mode for $1.6^{\circ} \mathrm{C}$ over a time of $164 \mathrm{~min}$. The calorimeter then took a $10^{\circ} \mathrm{C}$ step to $262^{\circ} \mathrm{C}$ where it again switched to adiabatic. The rate of heat evolution accelerated slowly until the temperature was $290^{\circ} \mathrm{C}$, then the rate decreased to zero by $305^{\circ} \mathrm{C}$. This exotherm lasted for $1546 \mathrm{~min}$.

It was possible to estimate the energy of the exothermic reaction from the following: total adiabatic temperature rise $\left(\sim 46.1^{\circ} \mathrm{C}\right)$, the specific heat of Hastelloy $\mathrm{C}(0.1 \mathrm{cal} /$ $\left.\mathrm{g} /{ }^{\circ} \mathrm{C}\right)$ and the weight of the cell $(19.7683 \mathrm{~g})$, the specific heat of the thermocouple clamp $\left(0.12 \mathrm{cal} / \mathrm{g} /{ }^{\circ} \mathrm{C}\right)$ and the weight of the clamp $(2.2 \mathrm{~g})$, a guessed specific heat of FECN-1 of $0.25 \mathrm{Cal} / \mathrm{g} /{ }^{\circ} \mathrm{C}$, and a sample weight of $0.4745 \mathrm{~g}$. The adiabatic temperature rise was equivalent to about $4.95 \mathrm{cal} /{ }^{\circ} \mathrm{C} / \mathrm{g}$ of $\mathrm{FECN}-1$ or $229 \mathrm{cal} / \mathrm{g}$. If the energy of the endotherm from $218^{\circ}$ to $240^{\circ} \mathrm{C}$ (reported by PNL as $9.6 \mathrm{cal} / \mathrm{g}$ ) is added, then the estimated exothermic energy was about $239 \mathrm{cal} / \mathrm{g}$ for $\mathrm{FECN}-1$.

No thermal-ruraway reaction was observed in this experiment, for the reason that most of the liberated energy heated the calorimeter cell and not the FECN-1 sample. This experiment indicated that the reactions that led to thermal runaway in a large isolated body of FECN-1 began at $209^{\circ} \mathrm{C}$. The sample lost $18.5 \%$ of its weight to gaseous products in this experiment.

FECN-1 ARC Experiment 2

In this experiment, an effort was made to confirm the hypothesis that a thermal runaway would begin at $209^{\circ} \mathrm{C}$. A $0.4934-\mathrm{g}$ sample of $\mathrm{FECN}-1$ in a IHC cell was held isothermally at $209^{\circ} \mathrm{C}$ for $67 \mathrm{~h}$. The calorimeter was biased to give a negative drift of $0.005^{\circ} \mathrm{C} / \mathrm{min}$. Under these conditions, the calorimeter drifted for about $10 \mathrm{~min}$ until the heater started, raising the sample temperature about $0.01^{\circ} \mathrm{C}$, then drift resumed. In this manner, thr sample was held at about $209^{\circ} \mathrm{C}$. If an exothermic reaction sufficient to cause a positive drift of $0.01^{\circ} \mathrm{C} / \mathrm{min}$ had begun, the calorimeter would have switched to its adiabatic mode. No exothermic reaction was observed. However, when we opened the sample, we noticed the odor of nitric oxide. We also 
noted that a welght loss of $0.0067 \mathrm{~g}(1.36 \%)$ had scaurred. The absence of a normal induction process exotherm during this time period could still be due to a phystal process endotherm was accentuated by the $0.005^{\circ} \mathrm{C}$ drift.

\section{FECN-1 ARC Experiment 3}

since we could not detect an exothermio reaction at the lower Iimit of the DTA endotherm, we decided to try a similar experiment at the upper temperature limit of the endotherm. A $0.4861-g$ sample of FECN-1 in a LHC cell was heated to $238^{\circ} \mathrm{C}$. The calorimeter switched immediately to the adiabatic mode and followed a temperature rise of $2.5^{\circ} \mathrm{C}$ for $2 \mathrm{k}$. At that time, the exotherm ended, the drift became negative (about $0.01^{\circ} \mathrm{C} / \mathrm{min}$ ), and the calorimeter held the temperature at $240^{\circ} \mathrm{C}$ for the next $45 \mathrm{~h}$. Again, we did not detect a significant self-heat reaction. The sample lost $0.0260 \mathrm{~g}(5.3 \%)$ in this experiment.

\section{FECN-1 ARC Experiment 4}

After these two failures to find a significant exotherm from an isothermal state, we decided to revert to step mode experiments again. A $0.5000-\mathrm{g}$ sample of FECN-1 was programmed to start at $258^{\circ} \mathrm{C}$ with $10^{\circ} \mathrm{C}$ steps at the end of every exotherm.

The calorimeter took about $40 \mathrm{~min}$ to heat from room temperature to $258^{\circ} \mathrm{C}$. The calorimeter switched to adiabatic mode as soon as it began testing for heat rise. By that time, the temperature was $260^{\circ} \mathrm{C}$. Heat was evolved at a decreasing rate until the temperature reached $264^{\circ} \mathrm{C}$, at which point the calorimeter took a $10^{\circ} \mathrm{C}$ step. This increased the reaction rate and reinitiated the adlabatic mode, which was held until the temperature was $283^{\circ} \mathrm{C}$, and the calorimeter took another $10^{\circ} \mathrm{C}$ step. There were two additional adiabatic regions followed by $10^{\circ} \mathrm{C}$ steps before the drift became negative. The total adiabatic temperature rise after subtracting steps was $25^{\circ} \mathrm{C}$, and the final temperature was $323^{\circ} \mathrm{C}$. The calorimeter continued stepping until the temperature was $423^{\circ} \mathrm{C}$, and another adiabatic region began, continuing until the temperature reached $453^{\circ} \mathrm{C}$.

The calorimetric equivalent for this run was about $4.92 \mathrm{Cal} /{ }^{\circ} \mathrm{C} / \mathrm{g}$ of $\mathrm{FECN}-1$. The estimate for the first exotherm that began at $260^{\circ} \mathrm{C}$ was $123 \mathrm{cal} / \mathrm{g}$. A similar estimate for the exotherm starting at $425^{\circ} \mathrm{C}$ was $147 \mathrm{cal} / \mathrm{g}$; a total of $270 \mathrm{cal} / \mathrm{g}$ for both. The weight loss for this experiment was $0.8660 \mathrm{~g}$ or $17.2 \%$ of the FECN-1. 


\section{FECN-1 ARC Experiment 5}

In the final ARC experiment, we started an 1sothermal mode run at $298^{\circ} \mathrm{C}$; a temperature high enough to ensure the selfheat reactions would cover both FECN-1 exotherms. A $0.5031 \mathrm{Lg}$ sample of FECN-1 in a LHC cell was heated as rapidiy as possible to $298^{\circ} \mathrm{C}$. An exotherm began immediately. The exothermic reaction inoreased in rate as the temperature rose, and for a time the dalorimeter could not maintain adiabatio conditions. The reaction required $148 \mathrm{~min}$ for a temperature rise of $66^{\circ} \mathrm{C}$. The calorimetric equivalent was estimated to be $4.67 \mathrm{cal} /{ }^{\circ} \mathrm{C} / \mathrm{g}$ for this run, and the exothermic reaction appeared to release about $308 \mathrm{cal} / \mathrm{g}$. The weight 10ss in this run is $0.0901 \mathrm{~g}$ or 17.9\% of the FECN-1. There was no evidence of any further exothermio reaction during $21 \mathrm{~h}$ of isothermal operation at $366^{\circ} \mathrm{C}$.

\section{Summary of ARC Experiments}

The ARC experiments are consistent with the DTA runs at IANL and the DSC run performed at PNI. At very slow heating rates, a decomposition exotherm can be detected at $200^{\circ} \mathrm{C}$. In a large body of $F E C N-1$, where the heat capactty of the container was negligible, this exotherm would eventually cause self-heating to about $1000^{\circ} \mathrm{C}$. Since chemical reaction rates accelerate with increasing temperature, there will be a point at which the reaction may accelerate to some sort of explosion. The ARC experiments are not sufficient to accurately predict the actual adlabatic heating rates for pure $F E C N-1$, but the heating rate should be slow while the temperature is below $240^{\circ} \mathrm{C}$ and both exothermic and endothermic reactions occur simultaneously. The first ARC experiment implies a self-heat rate of about $0.4^{\circ} \mathrm{C} / \mathrm{min}$ at $250^{\circ} \mathrm{C}$ for pure isolated FECN-1. The time to maximum reaction rate should then be measured in minutes, not hours. 


\section{DISTRIBUTION}

No, of

Coptes

\section{OFFSITE}

12 DOE/Office of Sclentific and Technical Information

J. C. Tseng

7A-075/FORS

U.S. Department of Energy 1000 Independence Avenue Washington, DC 20585

J. Antizzo

U.S. Department of Energy EM-351

Trevion II

Washington, DC 20585-0002

C. Terrel1

U.S. Department of Energy, Bldg. 704-S

P. 0. Box A

Atken, SC 29801

H. Walter

U.S. Department of Energy

EM-343

Trevion II

Washington, DC 20585-0C02

M. Walter

U.S. Department of Energy

EM-35

Trevton II

Washington, DC 20845-0002

D. Wiffen

U.S. Department of Energy

EM-35

Trevion II

Washington, DC 20585-0002
No. of

Coptes

G. Woodall

U.S. Department of Energy, MS - 1139

785 DOE Place

Idaho Falls, ID 83402

E. C. Ashby

225 North Avenue

Boggs Chemlstry Butlding

Georgta Institute of Technology

Atlanta, GA 30332

2 Brookhaven National Laboratory Butlding 129

Upton, NY 11973

ATTN: K. Bandyopadhyay

M. Retch

2 Westinghouse Savannah River

P. 0. Box 616

Atken, SC 29802

ATTN: N. E. Btbler

P. d'Entremont

$5 \quad L o s$ Alamos National Laboratory, M-1

P.0. Box 1163

Los Alamos, NM 87545

ATTN: H. H. Cady, MS-C920

J. C. DalTman, MS-C920

T. Larson, MS-P915

E. D. Loughran, MS-C920

H. Sullivan, MS-K557

3 Oak Ridge National Laboratory

P.0. Box 2008

Oak Ridge, TN 37831-6268

ATTN: D. Campbe11, MS-6268

C. Forsberg, MS -6273

T. Kress, MS -8088

F. Carlson

6965 North, 5th West

Idaho Falls, ID 83401 
No. of

Coptes

2

SAIC

20030 Century B1vd.

Sulte 201

Germantown, MD 20878

ATTN: R. Dantels

P. Hogrotan

C. Abrams

1987 Virginta

Idaho Falls, ID 83404

M. First

295 Upland Avenue

Newton Highlands, MA 02161

C. rorsberg

MS-6273, P.O. Box 2008

Oak Ridge, TN 37831

E. J. Hart

2115 Hart Road

Port Angeles, WA 98362

E. P. Horwitz

Chemistry Diviston

Argonne National Laboratory

Argonne, IL 60439

2 WINCO

P. O. Box 4000

Idaho Falls, ID 83403-4000

ATTN: A. Hoskins, MS -5217

D. D. Stemer, MS-2207

B. Hudson

Lawrence Livermore National Laboratory, L-221

P.0. Box 808

Livermore, CA 94550

M. Kaztmf

Room 24-102

77 Massachusetts Avenue

Cambridge, MA 02139
No, of

Coptes

P. Kiang

BDM, Trevton I, sutte 300

12850 Middlebrook Road

Germantown, MD 20874

D. Oakley

Los Alamos Nattonal Laboratory

University of Calffornta,

Sulte 310

409 12th Street, SW

Washington, DC 20024-2188

D. Ploetz

West Valley Nuclear

Services Co.

P.0. BoX 191, MS 305

West Valley, NY 14171-0191

J. Saveland 20030 Century B1vd., Sulte 201

Germantown, MD 20874

G. Schillauch

Atr Products \& Chemicals, Inc.

7201 Hamilton Blvd.

Allentown, PA 18195-1501

W. W. Schulz

727 Sweetleaf Drive

Wilmington, DE 19808

B. Schutte

EG\&G Idaho, Inc.

P.0. Box 1625

Idaho Falls, ID 83415-3940

S. Slezak

Sandia National Laboratortes, Diviston 6463

P.0. Box 5800

Albuquerque, NM 87185 
No. of

Coptes

W. J. Thomson

Department of Chemical

Engineering

Washington State University

Pullman, WA 99164

A. S. Veletsos

5211 Patsley

Houston, TX 77096

\section{FOREIGN}

J. Furrer

Karlsruhe Nuclear Center

7500 Karlsruhe

GERMANY

Gerard Naud

Centre d'Etudes Nucleaires de Cadarache

13108 Saint Paul Lez

Durance Cedex

Cadarache FRANCE

\section{ONSITE}

\section{DOE Rtchland Field Office}

G. H. Bracken, A6-80

R. F. Christensen, R4-04

J. M. Clark, A5-55

R. E. Gerton, A5-21

W. F. Hendrickson, N2-56

J. M. Hennig, A5-21

J. E. Newson, A6-80

G. Rosenwald, A5-21

W. A. Rutherford, A5-21

A. D. Toth, R4-04

B. J. Tucker, A4-35

Public Reading Room, Al-65
No. of

\section{Coptes}

\section{Westinghouse Hanford Company}

H. Babad, B3-68

D. G. Batde, R1-51

D. B. Bechtold, T6-50

M. L. BeT1, T5-50

R. M. Black, Rl-19

G. D. Blankenshtp, R1-62

R. J. B1 iss, B3-04

G. L. Borsheim, R2-11

W. F. Brehm, N2-01

W. W. Burk, L6-13

R. J. Cash, B3-68

J. L. Detchman, HO-O3

G. L. Dunford, R1-51

K. A. Gasper, B3-68

J. M. Grigsby, B1-35

W. H. Hamilton, R2-40

B. M. Hanl on, R1-80

M. N. Islam, R3-80

D. W. Jeppson, L5-31

J. M. Grtgsby, B1-35

R. T. Kimura, R1-49

N. W. Kirch, R2-11

M. J. Klem, R2-12

W. D. Leggett, L5-04

L. D. Muhlestein, N1-28

T. B. Powers, HO-31

J. G. Propson, R2-18

R. E. Raymond, R1-80

D. A. Reynolds, R2-11

W. G. Ruff, R2-53

M. H. Shannon, B1-35

D. D. Stepnewski, N1-31

D. J. Washenfelder, R1-43

D. D. Wodrich, R2-23

Waste Tank Safety Project

Ftles, R1-28 (2) 
No. of

Coptes

37 Pactfic Northwest Laboratory

R. T. Allemann, K5-19

L.M.G. Bal10U, P7-18

G. H. Bryan, P7-25

S. A. Bryan, P7-14

L. L. Burger, P7-25 (5)

T. H. Dunning, K2-18

R. T. Hallen, K2-12

M. S. Hanson, K1-51

B. M. Johnson, Jr., K1-78

W. W. Laity, K2-15

D. K. Lemon, K2-28

M. A. Lilga, K2-12

L. G. Morgan, P8-07

J.T.A. Roberts, K1-73

J. L. Ryan, P7-25

R. D. Scheele, P7-25 (5)

L. J. Sealock, K2-10

J. C. Spanner, K2-31

D. M. Strachan, K2-44

R. W. Stromatt, P7-22

J. M. Tingey, P7-25

D. S. Trent, K1-82

H. H. VanTuy 1, P7-25

Publishing Coordination

Technical Report Files (5) 

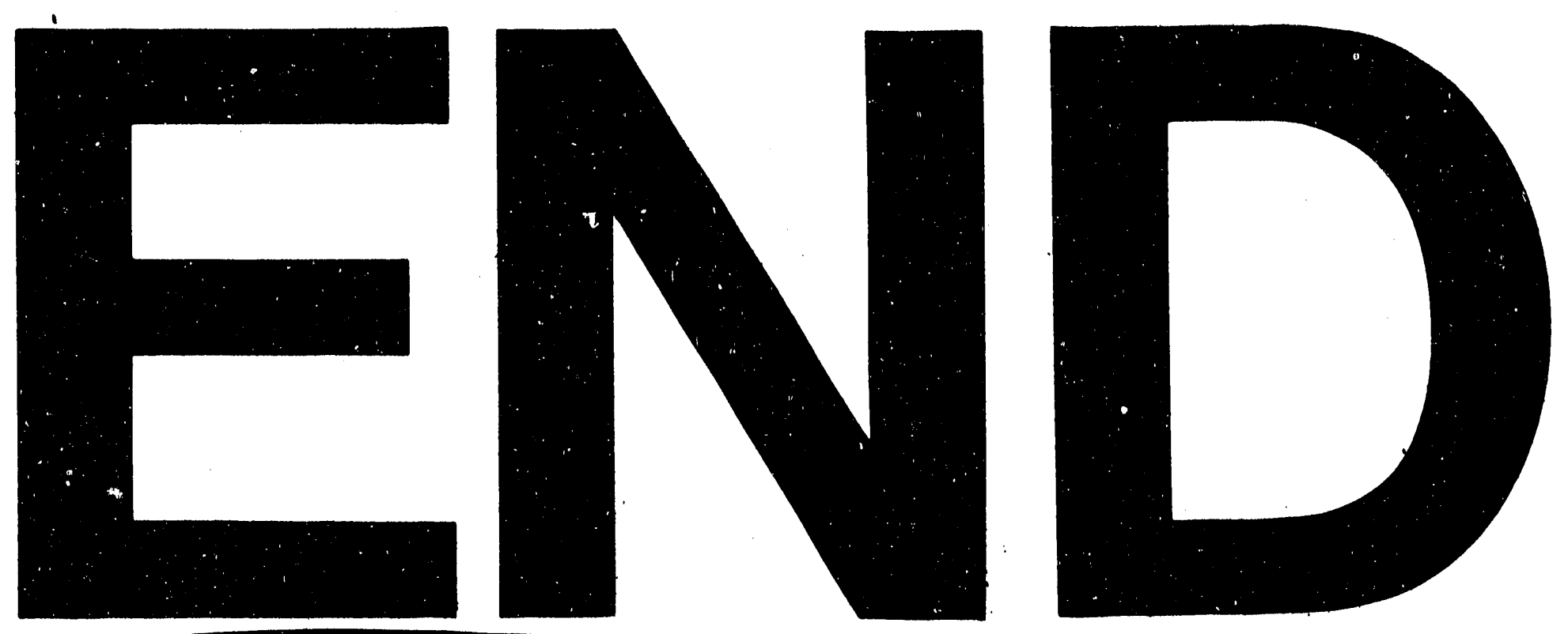

Mran
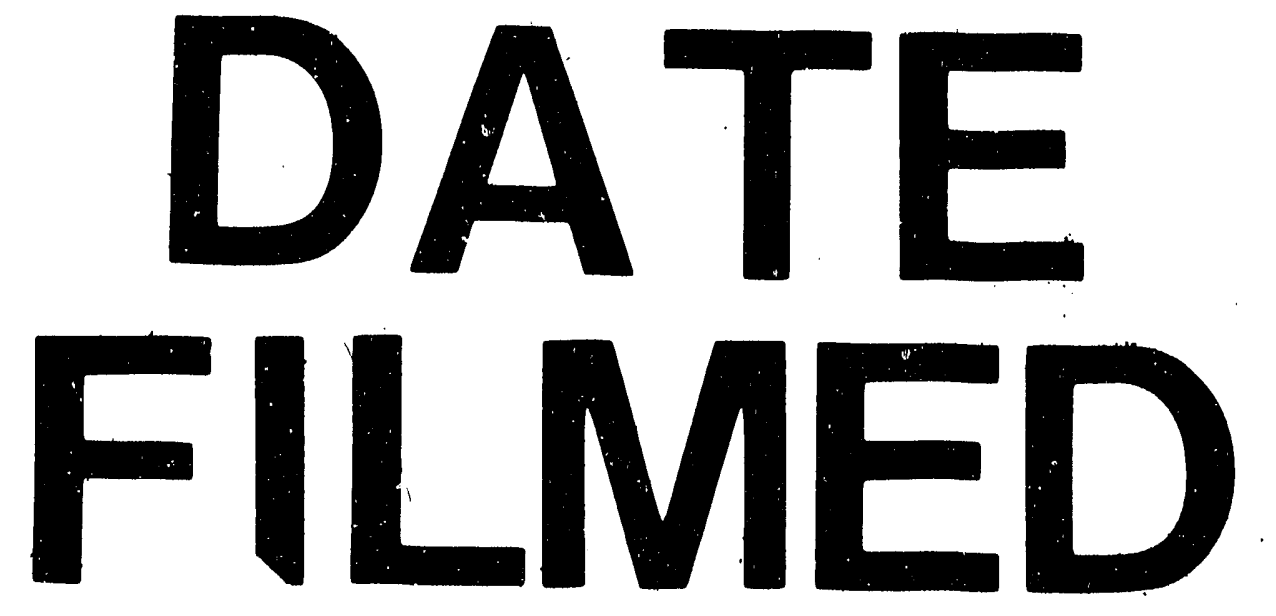

1

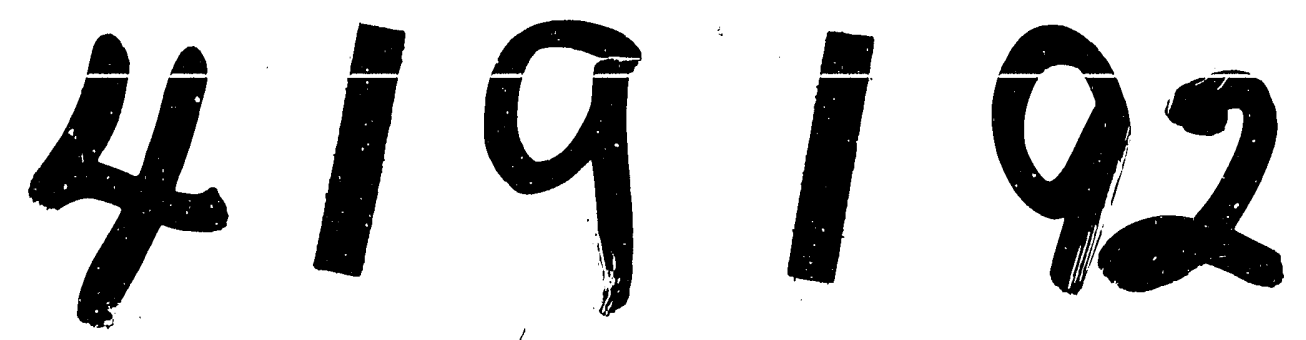

$I$ 
